CUADERNOS DE ESTUDIOS GALLEGOS, LXI Núm. 127 (enero-diciembre 2014), págs. 15-45

ISSN: 0210-847X

DOI: 10.3989/ceg.2014.127.01

\title{
SANTA MARÍA DE A FRANQUEIRA: DE MONASTERIO A SANTUARIO MARIANO
}

\author{
Marta Cendón Fernández \\ Universidad de Santiago de Compostela
}




\section{SANTA MARÍA DE A FRANQUEIRA: DE MONASTERIO A SANTUARIO MARIANO}

RESUMEN: Esta investigación pretende el estudio de un monasterio benedictino, Santa María de A Franqueira, con posibles raíces altomedievales que se convierte en un importante santuario mariano. Dicho monasterio se reconstruye en 1293, bajo el episcopado de don Juan Fernández de Sotomayor I, y se afilia a la orden del Císter siendo obispo don Juan Fernández de Sotomayor II y no como hasta ahora se había insistido a finales del siglo XIII. La obra se remata en 1342, data que aparece en un epígrafe bajo el tímpano siendo Gonzalo I, abad que la comenzó y acabó. Será él quien, como promotor, se efigia en el propio tímpano inmerso en la escena de la epifanía. La insistencia en los emblemas heráldicos de los Sotomayor indica el apoyo que el monasterio tuvo de este linaje, del que recibe importantes donaciones a finales del siglo XIV. Quizá por la vinculación que algunos miembros del mismo tuvieron con el monasterio cisterciense de Melón, en un momento en el que los monasterios benedictinos estaban en absoluta decadencia, se produjo su afiliación al Císter; esta se situaría entre 1421, fecha en la que el obispo de Tui ratifica la elección de un nuevo abad para este monasterio todavía benedictino y 1435 , data en la que no aparece entre los monasterios de dicha orden que han sido anexionados a la mesa capitular siguiendo la bula de Eugenio IV.

Asimismo el análisis de las manifestaciones artísticas que se corresponden con el gótico del siglo XIV, corrobora su similitud con obras del estilo orensano, a través del convento dominico de Ribadavia y no con las de los vecinos monasterios de Oseira o Melón, más reticentes con la imagen. Entre ellas, se insiste en la devoción mariana, la propia de un santuario que recibe peregrinos que acuden a él en busca de la salvación.

Palabras clave: Santa María de la Franqueira, Edad Media, monasterio, santuario mariano, Epifanía, Virgen María.

\section{SANTA MARÍA DE A FRANQUEIRA: DE MOSTEIRO A SANTUARIO MARIANO}

Resumo: Esta investigación pretende o estudo dun mosteiro beneditino, Santa María da Franqueira, con posibles raíces altomedievais que se converte nun importante santuario mariano. O devandito mosteiro reconstrúese en 1293, baixo o episcopado de don Juan Fernández de Soutomaior I e afilíase á orde do Císter sendo bispo don Juan Fernández de Soutomaior II e, non como ata agora se insistira a finais do século XIII. A obra remátase en 1342, data que aparece nun epígrafe baixo o tímpano sendo Gonzalo I, abade que a comezou e rematou. Será el quen, como promotor, se representa no propio tímpano inmerso na escena da epifanía. A insistencia nos emblemas heráldicos dos Soutomaior indica o apoio que o mosteiro tivo desta liñaxe, do que recibe importantes doazóns a finais do século XIV. Quizais pola vinculación que algúns membros deste tiveron co mosteiro cisterciense de Melón, nun momento no que os mosteiros beneditinos estaban en absoluta decadencia, se produciu a súa afiliación ao Císter; esta situaríase entre 1421, data na que o bispo de Tui ratifica a elección dun novo abade para este mosteiro aínda beneditino e 1435, data na que non aparece entre os mosteiros da devandita orde que se anexionou á mesa capitular seguindo a bula de Eugenio IV.

Así mesmo a análise das manifestacións artísticas que se corresponden co gótico do século XIV, corrobora a súa similitude con obras do estilo ourensán, a través do convento dominicano de Ribadavia e non coas dos veciños mosteiros de Oseira ou Melón, máis reticentes coa imaxe. Entre elas, insístese na devoción mariana, a propia dun santuario que recibe peregrinos que acoden a el en busca da salvación.

Palabras Clave: Santa María da Franqueira, Idade Media, mosteiro, santuario mariano, Epifanía, Virxe María.

\section{SANTA MARÍA DE A FRANQUEIRA: FROM MONASTERY TO MARIAN SHRINE}

ABSTRACT: This research studies a Benedictine monastery, Santa María de A Franqueira, probably with roots in the High Middle Ages that was converted into a very important Marian shrine. This monastery was rebuilt in 1293, under the episcopate of Juan Fernández de Sotomayor I and it was affiliated to the Cistercian order, during the episcopate of Juan Fernández de Sotomayor II and not, as previously thought, in the latter part of $13^{\text {th }}$ century. The building was finished in 1342, and this date appears in an inscription under the tympanum. Gonzalo was the abbot who began and finished the construction; as developer of the building works, he put his own portrait in an image of the Epiphany. The frequent repetition of Sotomayor heraldic emblems shows the support that this monastery received from this lineage, especially important donations at the end of the $14^{\text {th }}$ century. Its affiliation to the Cistercian order is perhaps due to the relationship that some members of this lineage had with the Cistercian monastery of Melón, when Benedictine monasteries were in complete decadence. It is dated between 1421, when the Bishop of Tui confirmed the new abbot of this still Benedictine monastery, and 1435, when it does not appear as a monastery of this order (bull of Boniface VIII), so it must be Cistercian.

Furthermore, the analysis of the $14^{\text {th }}$ century Gothic style, proves its similarity with the works of the Orensanian style, from the Dominican convent of Ribadavia and not with the artwork of the neighbouring monasteries of Oseira or Melón, which are more reticent with imagery. Devotion to the Virgin Mary is repeated throughout the shrine, as is common in all the churches that receive pilgrims looking for eternal salvation.

KEY words: Santa María de la Franqueira, Middle Ages, monastery, Marian shrine, Epiphany, Virgin Mary. 
Recibido/Received: 15/06/2014

Aceptado/Accepted: 08/09/2014

\section{EL ORIGEN MONÁSTICO}

a posición de la Gallaecia en el Finisterrae del mundo conocido no debe hacernos creer que permanecimos al margen de las innovaciones que se iban produciendo en la cristiandad. Así, los movimientos que se fueron introduciendo en la Iglesia, una vez que esta se había asentado, y que pretendían corregir los efectos de unas conversiones masivas y la paulatina dejadez tan pronto como la religión fue oficial, irán llegando a estas tierras, al tiempo que se adaptaban a ellas.

En época sueva (ca. siglo VI), las corrientes orientales, de una vida ascética en solitario, propias de los anacoretas, se van a complementar, gracias a la labor de San Martín de Dumio ${ }^{1}$, con momentos de vida en comunidad, dando así lugar al eremitismo; ello no implica que aquí no quedasen algunos anacoretas, incluso en época visigoda (ca. siglo VII), lo cual resultaba ya anacrónico ${ }^{2}$. En esta nueva época, de dominio de otro de los pueblos germánicos que se asientan en la Península, la vida religiosa es, cada vez, más comunitaria; en este caso es San Fructuoso de Braga, quien a través de su Regula Monachorum, expande el cenobitismo: una práctica de vida comunitaria en la que el cenobita — que no propiamente monje — vive con sus hermanos, si bien mantiene diversos momentos de oración en soledad.

Poco a poco se va dando paso a una vida comunitaria, propiamente monástica, donde la regla de San Benito de Nursia con su práctica del ora et labora, se extiende por todo el occidente europeo. En el caso gallego, la fundación de un monasterio como San Paio de Antealtares para dotar de mayor relevancia al culto al recién descubierto sepulcro apostólico (s. IX), es un claro reflejo de la buena fama de la que gozaba el clero regular. Y de nuevo una figura con nombre propio será trascendental para la historia del monacato en Galicia: San Rosendo

\footnotetext{
1 Todo ello ha sido matizado recientemente por los profesores Monteiro y Andrade; véase José M. Andrade Cernadas, "Los modelos monásticos en Galicia hasta el siglo XI", Archivo IberoAmericano, LXV/252 (2005), págs. 591-595.

2 Incluso pintoresco, como en el caso de Valerio del Bierzo.
} 
funda en el 942 el monasterio de Celanova ${ }^{3}$. Era miembro de una poderosa familia, que ocupa la sede episcopal de Dumio a lo largo de casi todo el siglo X y aunque tuvo una formación tradicional, en su concepción de la vida monástica va a incorporar influencias del monacato transpirenaico. Así, la riqueza con que se dotará el monasterio de Celanova, y la pretensión de que el monasterio no dependiese de ningún obispo, sino directamente del rey de León, guarda algunas semejanzas con el monacato de Cluny; esa misma influencia es la que incide en el fasto de las ceremonias litúrgicas. En realidad San Rosendo se propone experimentar un monacato de mayor rigor en la observancia que logre sustituir los anacrónicos excesos del misticismo, al mismo tiempo que la relajación y los abusos que caracterizaban a los monasterios familiares gallegos y que supondrá la progresiva desaparición de los monasterios dúplices; de este modo no es de extrañar que la figura del abad se delinee como básica en el seno de la comunidad que es quien lo va a elegir.

A finales del siglo IX se introduce la Regla de san Benito en España, gracias a la difusión que Benito de Aniano ha efectuado por todo el imperio carolingio, del que Cataluña formó parte. Por su parte la orden de Cluny se crea en 909 bajo los auspicios del duque Guillermo de Aquitania para reformar la orden benedictina y elevar el nivel ético y cultural del clero. Su fundador, el abad Odón, establece su sede en la conocida abadía de Cluny en la Borgoña francesa.

En el concilio de Coyanza en 1055, convocado por los reyes Fernando I y Sancha de León, se obliga a los monasterios a disponerse bajo la regla benedictina, escogida por el papado para unificar el monacato occidental, en el contexto de la reforma gregoriana, y se produce la sustitución del "antiguo rito hispano", por el rito romano. Alfonso VI favoreció la penetración cluniacense e intentó convertir el monasterio de Sahagún en el Cluny hispano ${ }^{4}$.

Por su parte el impulso de la Regla de san Benito en Galicia, se extiende hasta el siglo XII, si bien a mediados del siglo XII comienza su decadencia tocando fondo en el siglo XIV, cuando se produce una relajación total de costumbres ${ }^{5}$. En lo que atañe a la implantación de la orden cluniacense en Galicia fue lenta y

\footnotetext{
3 José M. Andrade Cernadas, "San Rosendo y Celanova", en Rudesindus. "San Rosendo. Su tiempo y su legado", Congreso celebrado en Mondoñedo, Santo Tirso (Portugal) y Celanova los días 27, 28, 29 y 30 de junio de 2007, Santiago de Compostela, Xunta de Galicia, 2009, págs.239250.

4 José M. Andrade Cernadas, "O monacato medieval en Galicia", en Galicia Terra Unica. Galicia románica e gótica, Ourense, Xunta de Galicia, 1997, págs. 62-69. Para el monacato benedictino, del mismo autor, Monxes e mosteiros na Galicia medieval, Santiago, Servicio Publicaciones USC, 1995 y El monacato benedictino y la sociedad de la Galicia medieval (siglos X al XIII), Sada, Edicións do Castro, 1997.

5 Enrique Martínez Ruiz (coord.), El peso de la iglesia. Cuatro siglos de Órdenes Religiosas en España, Madrid, Actas, 2004, pág. 80.
} 
poco numerosa - solo cuatro monasterios-, y no se produce hasta bien entrado el siglo XI, por la influencia de los grandes prelados compostelanos, Dalmacio y principalmente Diego Gelmírez, entre los años 1077 y 1100. Son conocidas las cordiales relaciones de Gelmírez con los abades generales de Cluny, san Hugo, Poncio y Pedro el Venerable, así como con varios monasterios y monjes de dicha congregación.

Pero pronto surge una reforma que pretende volver a la esencia benedictina frente a los excesos de Cluny: el Císter. La fundación de la Abadía de Citeaux por Roberto de Molesmes en 1098, es el hito de una nueva orden cuyo principal impulsor fue san Bernardo de Claraval (1090-1153) ${ }^{6}$.

El surgimiento de un monasterio cisterciense puede producirse de dos modos: como fundación ex novo o por afiliación. La primera requiere un control por parte de la abadía madre o fundadora, y su autorización definitiva depende del Capítulo General. Fueron muy pocos los monasterios cistercienses fundados ex novo en Galicia: lo habitual sería la refundación de viejos cenobios de origen altomedieval y, con frecuencia, su incorporación a la orden cisterciense tras un período - más bien corto- de pertenencia a la benedictina ${ }^{7}$. La historia del Císter en Galicia comienza con la fundación del Monasterio de Sobrado dos Monxes (Sobrado, A Coruña) en febrero de 1142. En los comienzos de la década siguiente de aquel siglo XII se completaría la que puede ser considerada como primera etapa fundacional del Císter en Galicia, y que englobaría otros dos monasterios constituidos ex novo bajo la orden de los monjes blancos: Meira y Melón. Una segunda etapa fundacional del Císter en Galicia se circunscribiría al último cuarto del siglo XII, hasta 1203, y ya con una peculiaridad que marca la diferencia con respecto a la etapa anterior de fundaciones ex novo: la afiliación a la orden cisterciense de monasterios que hasta entonces seguían una observancia benedictina. Es el caso de Armenteira, Monfero y Montederramo que tendrían unos orígenes altomedievales previos a la etapa benedictina, así como Oseira, Oia y Xunqueira de Espadañedo, de los que no se posee constancia de un origen anterior. En esta segunda etapa nos encontramos con dos monasterios femeninos, dependientes de Meira: Ferreira de Pantón (Pantón, Lugo) y Moreira (Castroverde, Lugo). En la implantación del Císter en la Galicia medieval puede definirse una tercera etapa, coincidente en general con el primer tercio del siglo XV, momento en el que se constata un nuevo conjunto de afiliaciones. La explicación a dicho proceso podría buscarse en la crisis económica y moral que arrastra el monacato desde el siglo anterior, pero también en evitar ser incluidos

\footnotetext{
6 E. Martínez Ruiz (coord.), El peso de la iglesia..., págs. 81-85.

7 Marta Cendón Fernández y David Chao Castro, "El Císter en Galicia”, en Los cistercienses en el reino de León hasta 1250, León, Instituto Leonés de Cultura, 2011.
} 
en la bula de Eugenio IV $^{8}$ que suprimía los monasterios benedictinos de la diócesis tudense en 1435, para pasarlos a la propiedad episcopal. Es este el caso del monasterio que nos ocupa, A Franqueira (A Cañiza, Pontevedra), así como San Clodio (Leiro, Ourense) y Acibeiro (Forcarei, Pontevedra) o el monasterio benedictino de los Santos Justo y Pastor de Toxosoutos (Lousame, A Coruña).

Centrándonos pues en el monasterio de Santa María de A Franqueira, nada sabemos de su nacimiento, sumidos en la leyenda en la que, como se verá, posee un papel fundamental el arranque del culto a la Virgen titular. Bien es cierto que en el Capítulo General del Císter de 1119, refrendado por el de 1134, se indicaba que todos los monasterios estuviesen dedicados a la Virgen ${ }^{9}$, pero, como quedará demostrado, nada tiene que ver el Císter en el origen de este monasterio. Ello no impide, como se pondrá de manifiesto, la existencia de una devoción mariana ligada a esta zona, que se irá potenciando a medida que su fama milagrosa atraiga a peregrinos y donaciones.

El primer testimonio de la existencia del monasterio es de 1063, cuando, según referencia del padre Jerónimo Ávalos, monje de San Martín Pinario ${ }^{10}$, Fernando I hace una donación a su abad Alvito y a los monjes que le acompañaban, especificando que la casa la habían fundado "viri boni in Sancta vita degentes" y otros, "post multa", la habían restaurado. La misma fuente recoge un privilegio expedido a su favor en 1144 por Alfonso VII. En él, junto a la confirmación de los derechos y propiedades que el monasterio tenía y a la concesión de todo lo que al rey le pertenecía en Luneda y en la misma Franqueira, se especifica que la comunidad, bajo el abad Odoario, vivía "sub regula ste, benedicti" ${ }^{11}$. Río cita

\footnotetext{
8 Protegió las congregaciones de benedictinos reformados de Santa Justina de Padua y San Benito de Valladolid.

9 "Se ordena que todos nuestros monasterios deben fundarse en honor de la Reina de cielo y Tierra" (1119); y "Que todos nuestros monasterios se dediquen en honor de Santa María. Porque nuestros antecesores y padres vinieron primitivamente de la iglesia de Molesmes, que está dedicada en honor de Santa María, el lugar del Cister, de donde nosotros salimos, por lo tanto decretamos que todas nuestras iglesias y las de nuestros sucesores se funden y dediquen en memoria de Santa María, reina de cielo y tierra" (1134).

${ }^{10}$ Recogida por Hipólito de Sa, Limia Jardón y Valle Pérez; véase Hipólito de Sá Bravo, El monacato en Galicia, La Coruña, Librigal, 1972, vol.II, pág.374; Francisco Xavier Limia JARDón, "Santa María de A Franqueira", en Fray Damián Yáñez Neira (coord.), Monasticon cisterciense gallego, León, Edilesa, 2000, vol I, pág. 279; José Carlos Valle Pérez, Santa María de A Franqueira. Monasterio Cisterciense, León, Edilesa, 2003, pág. 5.

11 "Deo et ecclesiae sat. marie de francarie vobisque domino adoario uius loci abbati fratibusque suis monachis ibi sunt regula ste. benedicti degendibus presentibus et futuris dono et confirmo totum hoc quod ad me iure pertinent in francaria et in villa lunaria...Facta Carta Legioni quando rex Garsia filiam imperatoris ibi uxorem duxit. Era MCLXXXII, mense junio", F. X. LIMIA JARDón, "Santa María de A Franqueira...”, pág. 272.
} 
también a un Segismundo en el monasterio en ese mismo año ${ }^{12}$. No obstante, ninguno de estos dos documentos se conservaba en el monasterio a mediados del siglo XVII ${ }^{13}$.

Tradicionalmente se insistía en el año 1293, como data de adscripción al Císter, recogida en el tumbo de fray Nicolás de Robles ${ }^{14}$. Ello no contaba con ningún apoyo documental y hoy poseemos constancia de que dicha fecha, si bien puede estar en relación con la de inicio del edificio, como a continuación se expondrá, nada tiene que ver con la citada orden. De hecho, en un documento hallado en el Archivo de la Catedral de Tui, por el investigador Pérez Rodríguez, en 1421 el obispo de Tui confirmaba la elección de un nuevo abad por parte del monasterio Sancte Marie de Francaria, ordinis Sancti Benedicti ${ }^{15}$, lo que muestra, sin lugar a dudas, que en esa fecha no es cisterciense.

Entre 1422 y 1434 se produciría, pues, la afiliación de A Franqueira a la orden del Císter. En 1435, los monasterios benedictinos de la diócesis de Tui debían ser visitados por el obispo de Ourense, por orden de Eugenio IV, para comprobar su mala situación y, de corroborarla, suprimirlos y anexionarlos a la mesa capitular tudense ${ }^{16}$. Ello, no solo no le afectó a A Franqueira, sino que en

\footnotetext{
${ }^{12}$ Laura Río Ramos, "Santa María da Franqueira”, en Mosteiros e conventos da Península Ibérica. Galicia, A Coruña, Hércules, 2008, tomo I, pág. 24. No obstante esta autora fecha erróneamente el documento de Alfonso VII en 1447.

${ }^{13}$ Como indica J.C. Valle, Santa María de A Franqueira..., págs. 5-6 no los menciona Fray Nicolás de Robles, autor, ca. 1656, del Tumbo hoy conservado en el AHN de Madrid. Tampoco figuran en las colecciones diplomáticas de los dos monarcas citados, Fernando I y Alfonso VII; por ello, "lo que se deduce de su contenido revela una secuencia que en nada se diferencia de la que podemos encontrar en otras muchas Casas monásticas: una comunidad surgida a partir de precedentes, verosímilmente eremíticos, que en un momento determinado de su evolución decide organizarse conforme a las prescripciones establecidas en la Regula Benedicti, referente imprescindible de la mayor parte de las colectividades monásticas que por entonces existían".

${ }^{14}$ F. X. Limia JaRdón, "Santa María de A Franqueira...”, pág. 272. Este monje se limita a decir: "Año del Nacimiento de Nuestro Señor y Redentor Iesu Christo de 1293 se fundó, edificó y dedicó esta santa Casa y Templo a honor de la siempre Virgen Madre de Dios, Protectora y Patrona, Nuestra Señora Santa María de la Franquera"

${ }^{15}$ El 22 de marzo de 1421 el obispo tudense confirma la elección, por el convento, de fray Juan como abad de Santa María da Franqueira, vacante ad presens monasterio conuentuali Sancte Marie de Francaria, ordinis Sancti Benedicti, nostre diocesis, per mortem fratris Stephani, quomdam vltimi et inmediati abbatis eiusdem... (ACT, Pergaminos, 13, núm. 38). Debo la nota completa a Francisco Javier Pérez Rodríguez, quien además de su libro Mosteiros de Galicia na Idade Media, Ourense, Deputación provincial de Ourense-Fundación Caixa Galicia, 2008, está ultimando una amplia obra sobre los monasterios en la Galicia Medieval. Quiero expresarle mi más profundo agradecimiento por su generosidad a la hora de hacerme llegar el archivo referente a A Franqueira y permitirme utilizar datos tan novedosos.

${ }^{16}$ Los monasterios citados eran Rebordáns, Angoares, Barrantes y Budiño (Pascual Galindo RoMeo, Tuy en la Baja Edad Media S. XII-XV, Madrid, El Noticiero, 1923, pág. 78. Ernesto Iglesias
} 
1481, el obispo don Diego de Muros le anexiona el suprimido monasterio femenino de Santa María de Casteláns.

Una nueva duda se suscita, acerca de quiénes fueron los introductores de la nueva orden en A Franqueira. Pérez Rodríguez ${ }^{17}$ considera que serían enviados monjes cistercienses desde Melón, quizás a instancias de los Sotomayor de Salvaterra. Desde luego es el monasterio más cercano, pero además, como se pone de manifiesto en el tímpano, la huella de los Sotomayor está presente en ambos centros. Por un lado, varios de los miembros de este linaje mandan inhumarse en Melón ${ }^{18}$, mientras Payo Sorred, el cual fue merino de Toroño y alcaide de Tui en los dos últimos decenios del s. XIV ${ }^{19}$, le donaría diversos cotos. Según fray Nicolás de Robles "el señor don Payo Sorrea de Sotomayor, primer señor que fue del alfoz de Salvatierra, hizo donaçión a este monasterio de los cotos de la Franquera, Zebrero, Huma, Sande y Pintelos ... con toda su jurisdiçión çivil y criminal ... Y no se contentó el dicho don Payo Sorrea de Sotomayor con haçer esta donaçión sino que él mismo supplicó al señor rey don Juan [I] y al señor rey don Henrique [III] se la confirmasen, los quales se lo hiçieron ${ }^{20}$. Asimismo tanto en la fecha de la posible erección de la iglesia, como en la de su afiliación al Císter, la sede tudense estaba regida por sendos obispos pertenecientes a este linaje: Juan Fernández de Sotomayor I (1286-1323), y II (ca.1395-1423) ${ }^{21}$.

AlmeIDA, "El monasterio de Santa María de Tomiño", Tui. Museo y archivo histórico diocesano, VI (1992), págs. 84-85.

${ }^{17}$ F. J. Pérez Rodríguez, Mosteiros de Galicia ..., pág. 185.

${ }^{18}$ Es el caso de Fernán Yáñez de Sotomayor, 1362, marzo, 7: "Et mando sepultar meu corpo dentro na iglesia do moesteyro de Santa María de mellon no moymento que y eu mandey fazer", en Ermelindo Portela SiLVA, La región del obispado de Tuy en los siglos XII a XV. Una sociedad en la expansión y en la crisis, Santiago, El Eco Franciscano, 1976, págs. 422-424. Asimismo el de Juan Fernández de Sotomayor, hijo de Fernán Yáñez de Sotomayor y de doña María: 1371, enero, 11, Milmanda: "Et mando sepultar meu corpo en o moesteiro de Santa Maria de Melon hu jaz meu padre et minna madre et meus avoos etcetera", en Miguel Romaní Martínez, M. ${ }^{a}$ José Portela Silva, Pilar Rodríguez Suárez, Mercedes Vázquez Bertomeu, Colección Diplomática de Santa María de Oseira (Ourense) 1310-1399, vol. III, Santiago de Compostela, Tórculo, 1993, doc. 1803, pág. 321.

${ }_{19}$ Vasco de Aponte, Recuento de las casa antiguas del reino de Galicia, Santiago, Xunta de Galicia, 1986, pág.106; José García Oro, La nobleza gallega en la Baja Edad Media, Santiago de Compostela, Liceo Franciscano, 1980-81, págs. 215-217; José Filgueira Valverde, "Miscelánea. Sobre Pay Sorred de Sotomayor", Museo de Pontevedra, III (1945), págs. 232-233.

${ }^{20}$ F. X. Limia JaRdón, "Santa María de A Franqueira...”, pág. 273.

${ }^{21}$ Marta Cendón Fernández, Los Sotomayor ante la muerte y su reflejo en el Arte (ss.XIV-XV), tesis de licenciatura inédita, Santiago de Compostela, 1991. Hay autores que consideran que hubo otro obispo don Juan (1351-1385), que también pudo pertenecer al linaje de Sotomayor y por ello mencionan a Juan Fernández de Sotomayor III: Suso VILA Botanes, A casa de Soutomaior (11471532), Noia, Toxosoutos, 2010, págs. 53-57. 
Ingresa en la Congregación de Castilla el 16 de agosto de 1521 mediante bula otorgada por el Papa León X, en concreto al priorato del colegio del Salvador de Salamanca $^{22}$. En el año 1572 don García Sarmiento de Sotomayor, IV señor del Sobroso y de Salvatierra ${ }^{23}$, ante el Capítulo General de la Congregación, intentó que el monasterio de A Franqueira recuperara su rango abacial, lo que no llegó a consolidarse. Y así, con escasos recursos, transcurrió la historia de este centro ${ }^{24}$ que había perdido el rango de monasterio, para convertirse en presidencia —así se denominaba a las casas de menor entidad - a lo largo de la Edad Moderna ${ }^{25}$.

En esta situación llegará a 1835, año en el que, como consecuencia de la desamortización de Mendizábal, los religiosos lo abandonan, pasando ulteriormente la iglesia a servir como parroquial, misión que sigue cumpliendo todavía en la actualidad.

\section{LA LEYENDA MARIANA}

Nos encontramos ante una de las leyendas marianas más populares de Galicia. En realidad la historia está ligada al topos de la ocultación de una imagen mariana durante la llegada de los musulmanes a la Península y su reaparición, ya durante el románico (ca. XI-XII), generalmente vinculada con paisajes agrícolas: en cuevas o rocas, fuentes o lugares de agua con virtudes milagrosas, o árboles especiales. Por otra parte, los descubridores suelen ser personas humildes: pastores, labradores, algún ermitaño. Los hallazgos suelen acompañarse de algún fenómeno meteorológico o fenómeno sobrenatural y se producen en lugares donde pudo haber un culto de antiguo origen, por lo que, cuando se intenta trasladar la imagen a un nuevo emplazamiento, esta se resiste. En la Península se hallan ejemplos de este tipo por todo el territorio: es el caso de la Virgen de Gua-

\footnotetext{
${ }^{22}$ José García Oro y M. José Portela Silva, A monarquía e os mosteiros gelegos no século XVI. A hora da recuperación, Noia, Grupo Filatélico e Numismático de Noia, 2009, págs. 47-48.

${ }^{23}$ Era hijo de Juan Sarmiento de Sotomayor y Beatriz de Noroña y Mendoza (véase F. X. Limia JARDóN, "Santa María de A Franqueira...", pág. 277). No se trataba, como indicaba Valle, del Conde de Salvatierra (J. C. VAlle, Santa María de A Franqueira..., pág. 12), título que será otorgado por Felipe III en 1613 a su hijo don Diego Sarmiento de Mendoza y Soutomaior. Para los antecesores de este linaje, Gonzalo F. Fernández SuÁreZ, La nobleza gallega entre los siglos XIV-XV. Los Sarmiento Condes de Ribadavia, Santiago de Compostela, El Eco Franciscano, 2002.

${ }^{24}$ Jesús Simón Pardo, La devoción a la Virgen en España. Historias y leyendas, Madrid, Palabra, 2003, págs. 285-288.

${ }^{25}$ María Seijas Montero, "Aproximación a la actividad económica del monasterio cisterciense de Santa María de A Franqueira”, en Galicia monástica. Homenaxe a María José Portela Silva, Santiago de Compostela, Universidade de Santiago de Compostela, 2009, pág. 248.
} 
dalupe $^{26}$, la de la Almudena ${ }^{27}$, Montserrat ${ }^{28}$, del Prado (Talavera de la Reina) ${ }^{29}$, entre otras muchas. En realidad, las leyendas pueden tener una base histórica: perdida la memoria de los lugares donde se pudieron esconder las imágenes, tras la reactivación económica que se produce a finales del siglo XI, se reanima la agricultura y la ganadería (se vuelven a roturar los campos y se volvió a apacentar el ganado), por lo que era natural que fueran apareciendo imágenes ocultas y que fuesen halladas por labradores y pastores, gentes de costumbres sencillas, cuyas prácticas se enmarcan en lo que consideramos religiosidad popular, que por sus ocupaciones estaban siempre en los campos, bosques y montañas.

Estas leyendas del hallazgo de una imagen y la posterior erección de un santuario mariano son también frecuentes en la propia Galicia ${ }^{30}$, como el de las Ermitas $\left(\mathrm{O}\right.$ Bolo) ${ }^{31}$ o el de la Barca (Muxía) ${ }^{32}$. No obstante, de la presencia de los musulmanes en Galicia es parte de esos topoi, en los que "os mouros", son casi sinónimo de antigüedad ${ }^{33}$, si bien estas tierras sufrieron más las invasiones normandas, que provocarían una crisis incluso en la organización de las sedes episcopales.

La antigüedad de la Virgen de la Franqueira se suele remontar al origen del eremitorio (siglo VI) si se tienen en cuenta las numerosas parroquias del entorno que se citan en el Parrochiale Suevum: Turedo (Touredo, parroquia de Luneda, limítrofe con la Franqueira); Tabudela (Taboexa, As Neves); Lucoparre

\footnotetext{
${ }^{26}$ Arturo Álvarez, Guadalupe: arte, historia y devoción mariana, Madrid, Stvdivm, 1964.

27 J. Simón PARdo, La devoción..., págs.285-288.

${ }^{28}$ Los numerosos casos catalanes están recogidos en un portal de la Generalitat que dedica un apartado a "Las Vírgenes encontradas" disponible en 〈http://www20.gencat.cat/portal/site/culturacatalana/menuitem.be2bc4cc4c5aec88f94a9710b0c0e1a0/?vgnextoid=d3ed5c43da896210VgnV CM1000000b0c1e0aRCRD\&vgnextchannel=d3ed5c43da896210VgnVCM1000000b0c1e0aRCR D\&vgnextfmt=detall2\&contentid=9654352101fd7210VgnVCM1000008d0c1e0aRCRD\&newLan g=es_ES> [Consulta: 25/05/2014].

29 J. Simón Pardo, La devoción..., págs. 375-380.

30 José CARDESo LiÑARES, Santuarios marianos de Galicia: historia, arte y tradiciones, A Coruña, Fundación Caixagalicia, 1995, págs. 11-17. Antonio Rodríguez FraIz, "Costumbres populares de las iglesias y santuarios marianos de Galicia”, Museo de Pontevedra, 14 (1960), págs. 89-141. Roberto J. López López, "Ermitas y santuarios marianos en Galicia en la Edad Moderna", en M. G. Meloni, O. Schena (coords.), Culti, santuari, pellegrinaggi in Sardegna e nella Penisola Iberica tra medioevo ed età contemporánea, Genova, Brigati, 2006, págs. 231-273.

31 Ana Pereira Salgado, El santuario de Nuestra Señora de las Ermitas, Ourense, Deputación Provincial de Ourense, 2008.

32 Xosé Antón Castro Fernández, El santuario de la Virgen de la Barca: tradición, arte y leyenda, Tesis de Licenciatura dir. Ramón Otero Túñez, Universidad de Santiago de Compostela, 1980, 2 vols. Xosé E. Rivadulla Porta, Santuario de Ntra. Sra. de la Barca-Muxía: leyenda, historia, arte, folklore, La Coruña, Imprenta Comercial, 1980.

${ }_{33}$ Mar Llinares García, Os mouros no imaxinario popular galego, Santiago de Compostela, Servicio de Publicacións USC, 1990.
} 
(Lougares, Mondariz), Aureas (Areas, en el arciprestazgo del Tea), Langetude (Languda, parroquia de Pías, Ponteareas). Desde luego su origen sería previo a la popularización del culto mariano, si bien, como se ha indicado, el propio surgimiento del monasterio es desconocido. Los datos documentales se remontan al último tercio del siglo XI, momento de la llegada del románico a Galicia y en el siglo siguiente hay constancia de su pertenencia a la orden benedictina. El culto mariano, si bien se ha asociado siempre al Císter, ya fue de gran importancia en el monacato benedictino como muestran los escritos de Pedro Damián ${ }^{34}$. Por otro lado, existen en Galicia importantes santuarios marianos pertenecientes a dicha orden; es el caso de Santa María de Ferreira de Pallares ${ }^{35}$, Nuestra Señora de Gracia (dependiente de Poio ${ }^{36}$ ) o la Virgen de Aguasantas ${ }^{37}$ en Cotobade (influido por Tenorio y Lérez) ${ }^{38}$.

El hallazgo ${ }^{39}$ se produce por parte de una vecina que apacentaba su ganado y cuya historia fue narrada por el propio Vicente Risco en estos términos ${ }^{40}$ : "Unha velliña que levaba a pacer o gando no que logo se chamou Coto da Vella, unha noite, ó se recoller, viu un resplandor no mais irto e viu a imaxe entremedio dos penedos, entre os términos de Luneda e Franqueira. Alí non se podía facer capela"41. En efecto, el lugar es rocoso y se encuentra a más de $900 \mathrm{~m}$ de altura, por lo que no era propicio para erigirle allí una capilla. Siguiendo el topos, se trata de una anciana, que lleva su ganado, la aparición se produce en medio de rocas y es anunciada por un resplandor. En este caso, no es la Virgen la que se niega a que la cambien de sitio, sino que al haberse producido el hallazgo en medio de dos lugares que se disputan la construcción del santuario, se tendrá que acudir a un "juicio de Dios". Así lo narró Risco: "Disputaron as dúas aldeas a quen había leval-a imaxe, e para pór paces, acordaron de poñel-a Virxe e mailas pedras nun carro do país, con xugadas dos diversos lugares levando os bois os ollos tapados e indo sin ninguén que os guiara. Os bois deron moitas voltas e, por fin,

\footnotetext{
${ }^{34}$ Domingo Luis GonZÁlez Lopo, "Orixe e desenvolvemento da devoción mariana nos santuarios de Galicia", en F. Javier Alonso Docampo (dir.), Magnificat, Vigo, Santuario da Nosa Señora da Franqueira; Concello de Vigo; Diócesis Tui-Vigo, 2013, pág. 122.

${ }^{35}$ José Ángel Rey Caíña, "La Abadía de Ferreira Pallares desde 898 hasta 1300", Cuadernos de Estudios Gallegos, 34, fasc. 99 (1983), págs. 89-115.

${ }^{36}$ Sergio Vázquez Rouco, San Xoán de Poio: monasterio, coto, parroquia, Pontevedra, Deputación Provincial de Pontevedra, 1998.

${ }^{37}$ Andrés María Solla García, Resumen histórico del santuario de Santa María de Aguassantas en Cotovad y novena a la Santísima, Pontevedra, Tipografía de Julio Antúnez, 1930.

${ }^{38}$ Domingo Luis González Lopo, "Orixe e desenvolvemento..., págs. 124-125.

${ }^{39}$ Clodio Fernández Pérez, "La romería de Nosa Señora de Franqueira", Narria: revista de artes y costumbres populares, 77-78 (1997), págs. 41-46.

${ }^{40}$ Vicente Risco, "Etnografia, cultura espiritual", en Ramón Otero Pedrayo (dir.): Historia de Galiza, Madrid, Akal, pág. 390.

${ }^{41}$ J. CARdeso Liñares, Santuarios marianos..., pág. 42.
} 
franquearon, colleron o camiño máis franco cara o que logo se chamóu — por esta causa- Franqueira" ${ }^{42}$. En el relato de Risco se obvia el hecho de que en el lugar donde pararon los bueyes había un manantial, que fue considerado, incluso hasta la actualidad, como milagroso y en el que las hendiduras de las rocas de las que mana el agua, son reflejo de las huellas de las ruedas en el momento de parada del carro ${ }^{43}$. De hecho la Virgen recibe el nombre de Nuestra Señora de la Franqueira o Nosa Señora da Fonte.

Un vez más aparece otro de los elementos recurrentes en estas leyendas, la presencia del agua curativa que suele estar tan vinculada a los santuarios marianos.

Se desconoce la fecha del hallazgo, si bien el siguiente hito en la historia del desarrollo del culto mariano en este lugar, sería la constancia documental de las donaciones y peregrinaciones. Lo que parece claro es que la devoción a la Virgen contaba con una larga tradición que llevaría a la construcción de un nuevo templo — como se verá- y a la consolidación de una peregrinación como se trasluce en documentos de donaciones ${ }^{44}$, desde el siglo XIII, aunque se multiplican en el XIV ${ }^{45}$, desde 1348, poco después de la fecha - 1343 - en la que, como se verá, se dataría la finalización del edificio que aquí se aborda y que se complementan con peticiones de peregrinaciones vicarias en los siglos XIV y $\mathrm{XV}^{46}$.

Una peregrinación que forma parte de la tradición y no de la documentación, tendría lugar en 1335, y se correspondería con la que habría llevado a cabo Isabel

\footnotetext{
${ }^{42}$ V. Risco, pág. 390.

${ }^{43}$ C. Fernández Pérez, "La romería...”, pág. 42.

${ }^{44}$ El primer documento en el que se hace referencia a las ofrendas a la Virgen de A Franqueira corresponde al testamento del escudero de Santiago de Compostela Pedro Eanes. Es del año 1243 y envía como ofrenda "diez talegas de trigo, diez talegas centeno, cinco carneros, veinte gallinas, y dos bueyes". Véase Javier Alonso Docampo, "A Franqueira y sus romerías", en F. Javier Alonso Docampo (dir.), Magnificat, Vigo, Santuario da Nosa Señora da Franqueira; Concello de Vigo; Diócesis Tui-Vigo, 2013, pág. 136.

${ }^{45}$ Testamento de don Nuño Fernández de Bendaña, arcediano de Reina en la iglesia compostelana, datado en 1348 y en el que lega cien "marabedis curtos a Santa Maria da Franqueira", Antonio López Ferreiro, Historia de la S.A.M.I. de Santiago de Compostela, Santiago de Compostela, Imp. y enc. del Seminario Conciliar Central, 1901, tomo VI, pág. 309, doc. núm. 72. Agradezco la cita a F. J. Pérez Rodríguez.

${ }^{46}$ M. ${ }^{a}$ Carmen Enríquez Paradela, Colección Diplomática del monasterio y convento de Santo Domingo de Ribadavia, Ourense, Museo Arqueolóxico Provincial, 1987, págs. 66-69 (Boletín Avriense, Anexo 8): 1361, diciembre, 19, Testamento de Juan Gómez, hijo de Gómez Lourenzo de Avión y de Tereija Afonso, doc. núm. 4: "Item mando yr en romaria por min hun homme ou moller con offerta e con candea a Santa María da Franqueira, tamaña candea como eu do meu estado", pág. 67. M. a José Portela Silva (ed.), Documentos da catedral de Lugo. Século XV, Santiago de Compostela, Consello da Cultura Galega, 2005, págs. 304-306: 1463, xaneiro, 8. Lugo, Testamento de Roi Domínguez, zapateiro, en el que se dispone que se envíe "hun home en romaría a Santa Maria de Guadalupe et outro home a Santa María de Franqueyra".
} 
de Aragón, luego Isabel de Portugal, "la Raíña Santa”. Habría seguido el camino próximo al Miño, que uniría Tui con Ourense, conocido como la vereda real ${ }^{47}$.

En la reiteración de elementos comunes a muchos de los santurios marianos, están incluso las propias datas de celebración: el lunes de Pentecostés (las Pascuillas), romería de primavera y el 8 de septiembre, romería de verano, que coincide con la festividad de la Natividad de la Virgen.

\section{MONASTERIO Y SANTUARIO MARIANO: ECOS ARTÍSTICOS DEL MEDIEVO}

Lo único que ha llegado a nosotros, a pesar de las reformas que se llevaron a cabo a lo largo de los siglos, es la iglesia. El resto del conjunto monástico que en un principio albergaría una comunidad benedictina, para más tarde acoger a una cisterciense, ha sufrido una total destrucción, salvo pequeñas piezas reutilizadas en obras posteriores, como la casa rectoral.

Antes de abordar el análisis del templo, conviene recordar lo ya indicado, acerca de la fecha en la que el monasterio de A Franqueira pasa a la orden del Císter. Si la opinión tradicional hacía coincidir la construcción del templo con el cambio de los monjes negros a los blancos, hoy se puede afirmar que este templo fue construido para una comunidad benedictina, que acoge una devoción mariana que se convierte en núcleo de peregrinación y ambas cosas explicarían la presencia de unos motivos que poco tienen que ver con las construcciones del Císter. Por las pistas que proporciona el estilo, esa data de 1293, que se solía consignar como la de su afiliación al Císter, podría ser la de inicio del edificio. Cabe pensar cuál es el motivo para reconstruir un monasterio benedictino, cuando esta orden ya se encontraba en decadencia. Pérez Rodríguez plantea la posibilidad de sea un momento próximo al "hallazgo" de la Virgen:

La manifestación de Nuestra Señora y la más que probable realización de milagros a partir de ese momento haría que el obispo de Tui — que, además, estaba más o menos relacionado con la comarca-se decidiese a reimpulsar un cenobio que, a finales del siglo XIII, debía ser uno de los menos brillantes de su diócesis, como lo demuestra la escasa documentación que parece haber tenido así como un dominio que ni siquiera a finales del XV parece especialmente extenso. La aparición mariana y la llegada de peregrinos al lugar, impulsada por la más que probablemente escasa comunidad de A Franqueira, será coronada con la intervención diocesana y la construcción de un nuevo templo que presumiblemente ampliaría

\footnotetext{
${ }^{47}$ Javier Alonso DocAmpo, “A Franqueira...”, pág. 136.
} 
el existente, además de instalar en él una imagen de la Virgen que canalizará la devoción popular hasta hoy ${ }^{48}$.

Efectivamente, como se ha indicado, lo que aparece es una imagen. La que hoy ocupa el camarín (lám.1), y por lo tanto el espacio preeminente, se suele datar en el segundo cuarto del siglo XIV ${ }^{49}$, coincidiendo con la construcción del edificio y parece realizada para presidirlo en la zona absidal, desde el momento de su construcción como ha indicado Valle ${ }^{50}$. Teniendo en cuenta que la fachada se data en 1343, como veremos, y la Virgen que la preside — inserta en una epifanía- es casi una réplica de la exenta, esta ha de ser anterior, por tanto de finales del siglo XIII o las primeras décadas del siglo $\mathrm{XIV}^{51}$, concebida como imagen de devoción de un pueblo que verá en ella la mejor ayuda para remediar sus males, curar sus dolencias y alcanzar la salvación. Se puede considerar, pues, que imagen y continente surgen de modo simultáneo y, desde luego, es la primera escultura mariana que se conserva, vinculada con el monasterio.

Por lo que se refiere a su iconografía se corresponde al tipo de la Sedes Sapientiae, "trono de sabiduría", tribuna en la que se sienta su hijo que porta un libro abierto en sus manos mientras ella eleva el brazo derecho en cuya mano sujeta una esfera, que puede corresponderse con un fruto, generalmente manzana —en la evocación Eva-Ave_— ${ }^{52}$ o con el orbe del que también es reina ${ }^{53}$; de hecho, además de vestir túnica, manto y velo, la imagen está coronada y se le superponen ricas coronas según las festividades y el paso de los siglos. El Niño dispone su mano derecha en actitud de predicación ${ }^{54}$, de la palabra contenida en el libro de la vida, que sujeta con la izquierda, delicadamente ayudado por su madre. A pesar de la tosquedad de la labra, agudizada por tratarse de una imagen

\footnotetext{
${ }^{48}$ Francisco Javier Pérez Rodríguez, manuscrito inédito de su libro sobre los monasterios gallegos, de próxima publicación, y al que agradezco, una vez más, su generosidad.

${ }^{49}$ Rocío Sánchez AmeIJeIRas, "Las artes figurativas en los monasterios cistercienses medievales gallegos", en Jose Rodrigues y José Carlos Valle Pérez (coord.), Arte del Císter en Galicia y Portugal, A Coruña, Fundación Calouste Gulbenkian-Fundación Pedro Barrié de la Maza, 1998, pág. 109.

${ }^{50}$ J. C. Valle, Santa María de A Franqueira..., pág. 44. F. X. Limia Jardón, "Santa María de A Franqueira...", pág. 286.

${ }^{51}$ Andrés F. Fuertes Palomera, "Auga da fonte / Agua de la fuente", en F. Javier Alonso Docampo (dir.), Magnificat, Vigo, Santuario da Nosa Señora da Franqueira; Concello de Vigo; Diócesis Tui-Vigo, 2013, pág. 82.

${ }^{52}$ Máximo Gómez Rascón, Theotókos. Vírgenes medievales de la diócesis de León, León, Edilesa, 1996, págs. 27-30.

${ }^{53}$ M. Gómez Rascón, Theotókos..., pág. 66.

${ }^{54}$ M. ${ }^{a}$ Dolores Fraga Sampedro, "El poder de la palabra: imágenes de predicación en la Edad Media Hispana”, e-Spania [En línea], 3 juin 2007, Puesto en línea el 21 juin 2007 [consultado el 5 de mayo de 2014].
} 


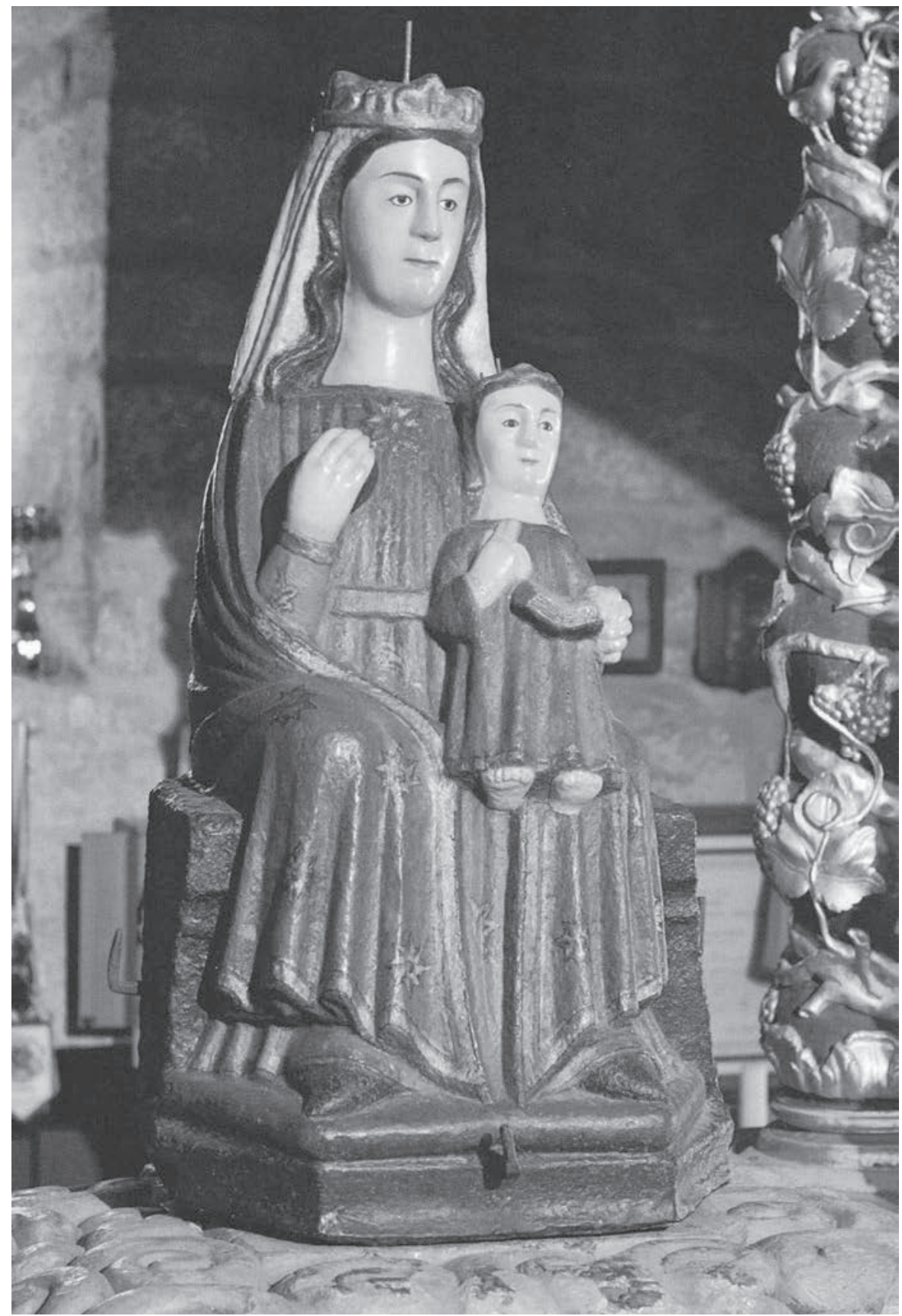

Lámina 1 
pétrea $^{55}$, no se olvidan elementos esenciales en la iconografía que muestran una evolución en la representación de la Virgen con el Niño. Se insiste en la predicación al presentar el libro abierto y el gesto de sus dedos. De hecho Fuertes indica que la iconografía de esta imagen de la Franqueira es una expresión artística promovida por las órdenes mendicantes en el siglo XIII ${ }^{56}$. Precisamente, como ya se ha insistido, esta imagen estaría en relación con un monasterio benedictino, en cuya iconografía, como se verá, han influido de modo muy claro modelos orensanos, entre ellos el convento dominico de Ribadavia, mucho más que los de los monasterios cistercienses, más reticentes a la imagen.

En cuanto a la iglesia, la planta tiene una configuración muy sencilla, de una sola nave rectangular, amplia, dividida en cuatro tramos, y una capilla, también única y rectangular, seguramente dividida en tres tramos, si bien hoy persisten solo dos ${ }^{57}$.

En el interior (lám. 2) se muestra con claridad esta estructura, de amplia nave y considerable altura, con cubierta plana sostenida por arcos fajones apuntados - jalonados por variados signos lapidarios - que descansan sobre ménsulas decoradas con florones octifolios de configuración geométrica. Los muros laterales se elevan sobre un banco corrido, que les sirve como basamento. En el lado norte se abren una puerta y dos ventanas: la primera en el tercer tramo - desde el acceso occidental - mientras las segundas lo hacen en el segundo y cuarto. Por su parte, en el lado sur, si bien la puerta coincide con la del lado opuesto, las ventanas se abren en el primero y en el tercero, sobre la puerta, siendo este lienzo fruto de reformas posteriores. Ciertamente los accesos laterales no muestran cara al interior ninguna relación con la construcción medieval del templo; no así las ventanas, cuyos capiteles poseen una esbeltez propia del gótico y una ornamentación a base de motivos vegetales o zoomórficos, que se combinan con pequeñas cabezas humanas. Entre estos últimos destaca uno de la única ventana del muro sur, donde dos aves de mayor tamaño, sujetan con sus garras a otras más pequeñas, mientras picotean sus cabezas, en tanto que entre las superiores emerge una cabeza humana. Sin embargo, los capiteles de la nave que dan acceso hacia la cabecera, tienen una estructura troncopiramidal, con decoración vegetal el del lado norte y sendos híbridos con cuerpo de cuadrúpedo y rostro humano que se utiliza en los ángulos, punto de convergencia de los cuerpos animales.

Nos encontramos, pues, con una estructura reiterada en el románico rural, y que en los siglos XIV y XV se muestra en el llamado "gótico marinero" —clasi-

\footnotetext{
${ }^{55}$ Su peso, así como su devenir como imagen procesional, obligaron a la realización de una réplica en poliéster a finales del siglo pasado. Véase Andrés F. Fuertes, "Auga da fonte...", pág. 82.

${ }^{56}$ Andrés F. Fuertes, “Auga da fonte...”, págs. 82-83.

${ }^{57}$ J. C. VAlle, Santa María de A Franqueira..., págs. 15-16.
} 


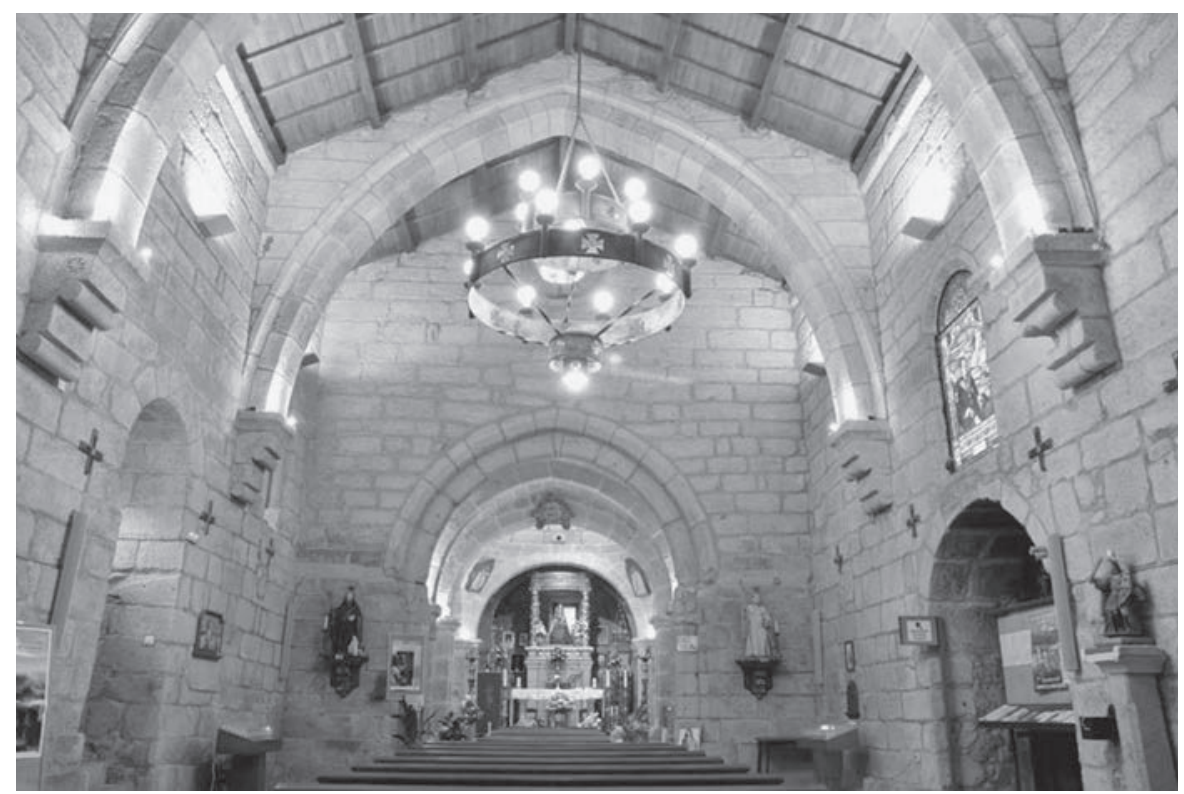

Lámina 2

ficación acuñada por Caamaño Martínez ${ }^{58}$ — de la primera etapa (1250-1350) a su vez la nave, por su amplitud y su cubierta de madera sostenida sobre amplios fajones, se asemejaría a otro tipo de templos góticos, que, en cambio, poseen cabecera hemipoligonal con bóveda de crucería, semejante a templos de clarisas y dominicas ${ }^{60}$. Por lo que atañe a los elementos ornamentales, las ménsulas evocan a los de otros edificios de la diócesis como la colegiata de Baiona, si bien aquí alternan motivos cilíndricos con los paralelepipédicos, mientras que en los capiteles, en esta caso más toscos, las relaciones nos podrían llevar a Santo Domingo de Ribadavia.

La cabecera sufre una importante reforma en el barroco, en torno a 1699, para dar mayor énfasis a la Virgen titular, con una estructura cupulada que centra un espacio que daría lugar a dos tramos hacia oriente y dos hacia occidente y sendas naves hacia el norte y el sur, a modo de naves laterales. En las pechinas de

\footnotetext{
58 Jesús M. ${ }^{a}$ CaAmaño Martínez, Contribución al estudio del gótico en Galicia, Valladolid, Universidad, 1962.

${ }^{59}$ Ramón Yzquierdo Perrín, y Carmen Manso Porto, "Arte medieval (II)”, en Galicia. Arte, tomo XI, La Coruña, Hércules, 1996, pág. 321. A ella pertenecerían Santa María a Nova de Noia, Santa María de Muxía, y el Espíritu Santo de Muros.

${ }^{60}$ R. Yzquierdo Perrín, y C. Manso Porto, “Arte medieval (II)...”, pág. 328. Sería el caso de Santa María/Mariña de Lesa (Coirós, A Coruña).
} 
la cúpula se disponen relieves datables en el siglo XVIII con las representaciones de cuatro santos cistercienses: San Bernardo y San Esteban Harding, hacia el este, y San Alberico y San Roberto, hacia el oeste ${ }^{61}$.

Por lo que respecta al exterior, la portada occidental es la que ofrece mayor riqueza dentro de lo que sería el edificio medieval. No obstante, en las laterales norte y sur, se hallan algunos restos dignos de reseñar. Así, en el lienzo mural del lado norte se observan los cuatro tramos que se apreciaban en el interior, separados por sendos contrafuertes. En el primero hacia el oeste se levanta una torre, erigida en su parte baja a principios del siglo XVIII ${ }^{62}$, mientras el remate se correspondería con la concesión del permiso para la construcción de una nueva torre que se erige entre 1893 y 1895. En el segundo y cuarto tramos se vuelven a apreciar las ventanas, con capiteles vegetales muy deteriorados. Entre los contrafuertes que enmarcan el tercer tramo, se despliega un arco de medio punto, a modo de pórtico, en cuyo arranque se han dispuesto dos imágenes: una femenina y otra masculina. La femenina, dispuesta hacia el lado izquierdo del espectador está en pie, ataviada con hábitos monjiles, con toca y cofia que cubre su barbilla. Porta en su mano izquierda una cartela; la posición de la mano derecha podría corresponder al Fiat. Sin embargo, aunque como indica Valle ${ }^{63}$, por lógica la figura masculina debería de corresponder al arcángel Gabriel, tratándose pues, de una Anunciación, tema frecuente en la época y más en un conjunto mariano, su estado de conservación deficiente dificulta su identificación, y, en realidad parece una figura barbada y con cabello largo que nada tiene en común con la imagen angélica.

En relación con el lado sur, se traduce, de nuevo, lo ya indicado para el interior y el muro opuesto: los cuatro tramos de la nave se separan por medio de contrafuertes, con la ventana medieval en el primero - que a pesar del desgaste presenta capiteles vegetales - , así como la puerta que daría acceso a las dependencias conventuales, retocada, según resalta Valle, tal como figura en la clave del arco, en $1955^{64}$.

Finalmente, y, sin duda lo más destacado, es la fachada occidental, en concreto la portada (lám. 3). Es la pieza clave para tratar cuestiones de cronología, estilo e iconografía que convierten a la iglesia de la Franqueira en uno de los ejemplos más relevantes del gótico de la diócesis de Tui.

\footnotetext{
${ }^{61}$ J. C. Valle, Santa María de A Franqueira..., pág. 48.

${ }^{62}$ J. C. Valle, Santa María de A Franqueira..., pág. 16.

${ }^{63}$ J. C. Valle, Santa María de A Franqueira..., pág. 21.

${ }^{64}$ J. C. Valle, Santa María de A Franqueira..., pág. 21.
} 


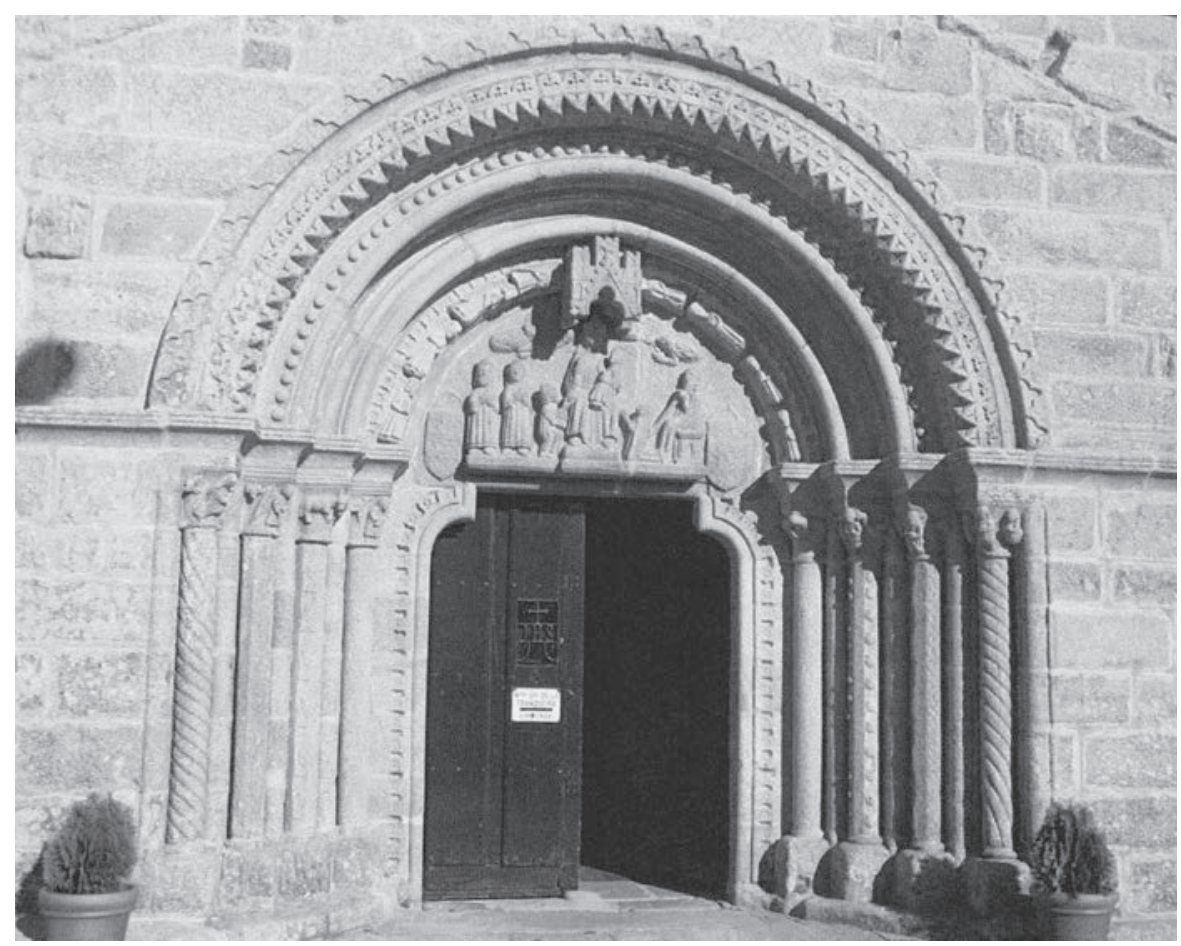

Lámina 3

Por lo que respecta a la cronología, contamos con un epígrafe fundamental bajo el dintel. Según la transcripción de Ávila y La Cueva ${ }^{65}$, rezaría:

Era MCCCLXXXI. Frei Gonzalo Primo he que començou e acabou.

Si seguimos lo aquí indicado, estaríamos en el año 1343, data que podría coincidir con el remate general del edificio, que según Fray Nicolás de Robles habría tenido su origen en 1293, año en el que "se fundo, edificó y dedicó, esta santa casa y Templo" "66. En efecto, esta data que se suele considerar la de su adscripción al Císter, sería, como ya se ha indicado, la del inicio de la edificación, para una comunidad benedictina, en un centro donde el culto mariano tiene especial importancia. Por su parte este arco cronológico coincide bien, como a continuación se indicará, con el estilo que, desde la Claustra Nova ourensana, se expande por otros núcleos gallegos.

${ }^{65}$ J. C. VAlle, Santa María de A Franqueira..., pág. 32. Véase asimismo Francisco Ávila y la Cueva, Historia civil y eclesiástica de la ciudad de Tuy y su obispado, 4 tomos, Archivo de la Catedral de Tui, 1852. Ed. facs. Consello da Cultura Galega, 1995; tomo II, págs. 352-353.

${ }^{66}$ F. X. Limia JaRdón, “Santa María de A Franqueira...”, pág. 283. 
Pero antes de las consideraciones de estilo conviene insistir en el epígrafe donde se menciona el nombre del impulsor, Fray Gonzalo I. Desconocemos quién era este personaje. No tenemos constancia de que los cargos de abad tuviesen relación con los promotores laicos de los monasterios; es más, si repasamos los abadologios de los monasterios gallegos, tan solo aparece el nombre del abad, en muchos casos homónimos, lo que ha llevado a ciertos errores en la interpretación de la documentación, y no es hasta finales del XIII cuando comienza a aparecer algún apellido, uno solo, que no permite establecer ninguna vinculación con la nobleza de la época ${ }^{67}$. Por eso se trata de un Gonzalo, el primero de este nombre, y coincidimos con Valle ${ }^{68}$ en que puede corresponderse con el que en posición de donante ${ }^{69}$ se figura en el tímpano, ya que en su indumentaria se aprecia con claridad la cogulla. Rectificamos, pues lo que indicamos en otro lugar, donde considerábamos que podía tratarse del obispo Juan Fernández de Sotomayor $\mathrm{I}^{70}$, ya que, de ser así, portaría la indumentaria propia de la condición episcopal, como se puede observar en el ejemplo de Santa María a Nova de Noia, promovida por el arzobispo compostelano Fray Berenguel de Landoria. No obstante, en el tímpano (lám.4), a pesar del desgaste, se aprecian dos blasones pertenecientes al linaje de Sotomayor, que, como se ha indicado, posee una especial vinculación con el monasterio. En este sentido, no poseemos datos que permitan afirmar que Fray Gonzalo fuese un Sotomayor y por tanto le correspondiesen a él los escudos ${ }^{71}$, pero por su tamaño, y el propio hecho de figurar los tiracoles, indicarían el reconocimiento de un linaje en medio de una temática religiosa ${ }^{72}$. Sánchez Ameijeiras señaló cómo esta presencia de los tiracoles era frecuente en las arcas de algunos sarcófagos, sobre los cuales, efectivamente se colgaban los emblemas heráldicos. Ella misma desconoce la existencia de ceremonias en las que se colgasen los blasones en las portadas y, considerando que estamos ante una iglesia cisterciense, se apoya en algunas metáforas de San Bernardo que comparaban el templo de Salomón con la sobriedad de los templarios en cuyas casas, esos monjes caballeros, colgaban tan solo los escudos. En su argumentación concluye que en Galicia la obra de "Bernardo vendría, en cambio, a justificar la intromisión de los caballeros en los asuntos monásticos y su protagonismo en la decoración de las portadas" ${ }^{\text {"73 }}$. Teniendo en

\footnotetext{
${ }^{67}$ Marta Cendón Fernández y David Chao Castro, pág. 84.

68 J. C. Valle, Santa María de A Franqueira..., pág. 30.

${ }^{69}$ Marta Cendón Fernández y Dolores Barral Rivadulla, "Donantes y promotores: su imagen en la plástica gótica gallega", Semata, 10 (1999), monográfico dedicado a Cultura, poder y mecenazgo, págs. 389-418.

${ }^{70}$ M. Cendón Fernández y David Chao Castro, “El Císter en Galicia...”, pág. 110.

${ }^{71}$ A diferencia de lo que considera J. C. Valle, Santa María de A Franqueira..., pág. 30.

72 R. Sánchez Ameijeiras, "Las artes figurativas...”, pág. 117.

73 R. SÁnchez Ameijeiras, "Las artes figurativas...”, pág. 117.
} 


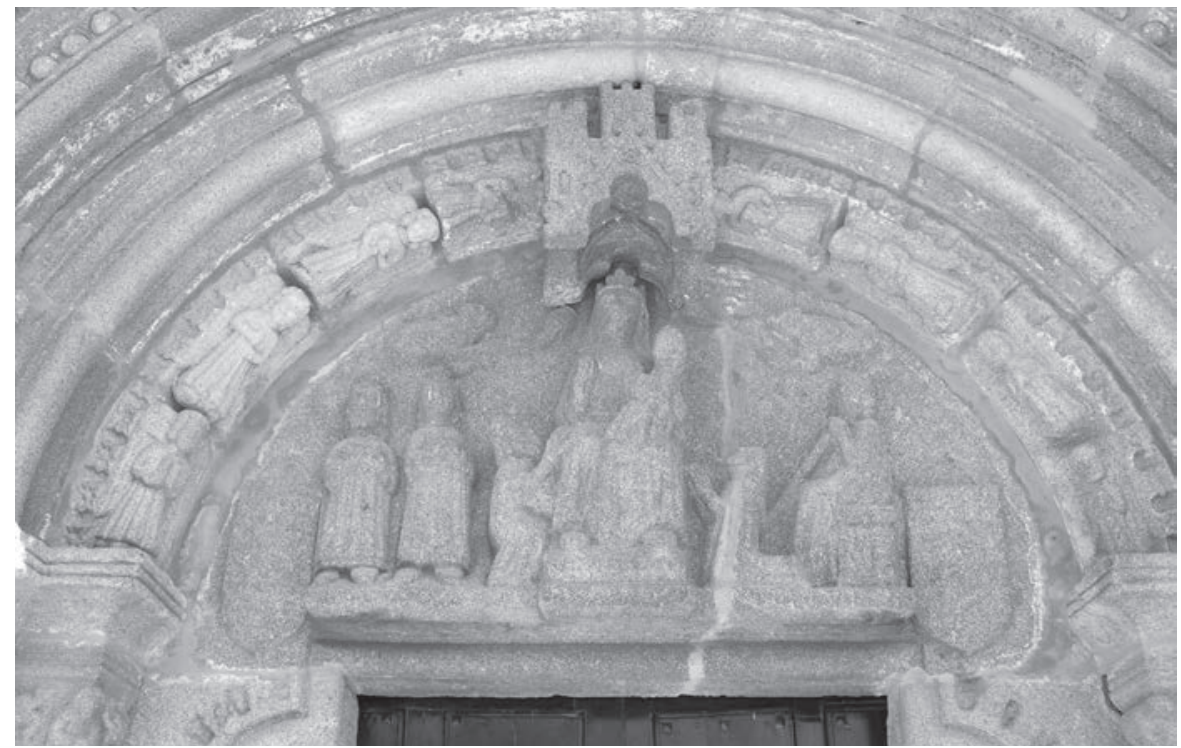

Lámina 4

cuenta las novedades que aquí se aportan, no sería necesario explicar el tímpano en un contexto del Císter, mucho más reticente con la imagen, sino con un monasterio benedictino. Asimismo, como se ha indicado, los Sotomayor protegen A Franqueira desde su inicio, y, no necesitamos la presencia de un miembro laico del linaje, pues es muy posible, como indicó Limia ${ }^{74}$, que el obispo de la diócesis don Juan Fernández de Sotomayor I haya desempeñado un papel fundamental en la construcción de la iglesia, así como el otro obispo del mismo linaje en su introducción en la orden del Císter. Por otro lado, hacia finales del siglo XIV será la cabeza del linaje, Paio Sorred, quien le haga donaciones. De todo ello, además de los blasones de la portada, han quedado muestras como otra labra heráldica hoy reutilizada en la casa rectoral ${ }^{75}$.

Desde el punto de vista del estilo, una de las cuestiones que puede llamar la atención es la directriz semicircular de las arquivoltas. Sin embargo, no son extraños los ejemplos gallegos, en los que, no solo se observa esta directriz —así el tímpano de la fachada de Santa María a Nova de Noia, de 1327_, sino que hay una clara coincidencia en el tema: la Epifanía, la presencia del donante e incluso en la cronología, plasmada en sendos epígrafes y correspondiente, en todos los casos, a la primera mitad del siglo XIV.

\footnotetext{
${ }_{74}$ F. X. Limia Jardón, “Santa María de A Franqueira...”, pág. 285.

75 L. Río Ramos, "Santa María da Franqueira...”, pág. 30.
} 
Por otra parte, aunque estilo e iconografía nos van a llevar a las mismas fuentes, conviene insistir de modo global en que el estilo, como ya fue indicado por Manso $^{76}$ y por Valle ${ }^{77}$, se corresponderían con lo que Moralejo ${ }^{78}$ denominó "disolución del estilo orensano", que comenzaría en torno a 1320-1325, época en la que se difunde de modo notable por algunas iglesias mendicantes, entre las que destaca, por su proximidad geográfica a A Franqueira, el convento de Santo Domingo de Ribadavia que por entonces pertenecía a la sede tudense. Las similitudes ornamentales en esta fachada con motivos propios de dicho estilo son enormes: la decoración de bolas, octifolias con botón central y puntas de diamante que jalonan tres de las cuatro arquivoltas, e incluso la estructura del vano de acceso, así como su decoración floral, con rosetas, que resulta muy semejante a la portada lateral norte de la iglesia de Santo Domingo de Ribadavia, datada por Manso ca. $1310^{79}$.

Por su parte, en la ornamentación de las columnas de la fachada se reiteran las bolas, un trenzado y aparecen curiosos castillos y conchas de vieira. La presencia de desgastados leones y castillos en los plintos sobre los que descansan las columnas, habría de ponerse en relación con motivos también frecuentes en los conjuntos mendicantes; es el caso de la portada occidental de San Francisco de Betanzos, pero asimismo son motivos que se representan en capiteles, como los de San Francisco de A Coruña, en cuyo caso Barral ${ }^{80}$ indica que puede tratarse de la representación del escudo de Castilla y León, como motivo preheráldico que se repite en un capitel procedente del convento dominico de A Coruña, en San Francisco de Ourense y en Santo Domingo de Ribadavia, una vez más el modelo más cercano al conjunto de A Franqueira. Las veneras, tal vez hagan referencia a su carácter de centro de peregrinación, en una asimilación con la peregrinación a Compostela.

Por último habría que destacar la iconografía. El tímpano no ofrece dificultades en su análisis, ya que se trata de una epifanía, con numerosos precedentes en Galicia $^{81}$ y que se enmarcaría dentro del grupo del estilo orensano y no de la tra-

\footnotetext{
${ }^{76}$ R. Yzquierdo Perrín, y C. Manso Porto, “Arte medieval (II)”..., pág. 292.

77 J. C. Valle, Santa María de A Franqueira..., pág. 47.

${ }^{78}$ Serafín Moralejo Álvarez, Escultura gótica en Galicia (1200-1350), resumen de la tesis doctoral, Santiago de Compostela, 1975.

${ }^{79}$ Carmen Manso Porto, Arte gótico en Galicia: los dominicos, La Coruña, Fundación Pedro Barrié de la Maza, 1993, tomo I, págs. 253 y 315, tomo 2, lám. 91.

${ }^{80}$ Dolores Barral Rivadulla, Arte y arquitectura en el Convento de San Francisco de A Coruña, Ferrol, Edicións Embora, 2007, pág. 88.

${ }^{81}$ Jesús M. ${ }^{a}$ CaAmaño Martínez, "Seis tímpanos compostelanos de la adoración de los Reyes", Archivo Español de Arte, 31 (1958), págs. 330-338. M. Cendón Fernández y D. Barral RivaDULla, "Donantes y promotores...", pág. 404. Desde la representación mateana en el trascoro de la catedral compostelana, al tímpano de la Corticela, y ya con presencia de donantes, los de San
} 


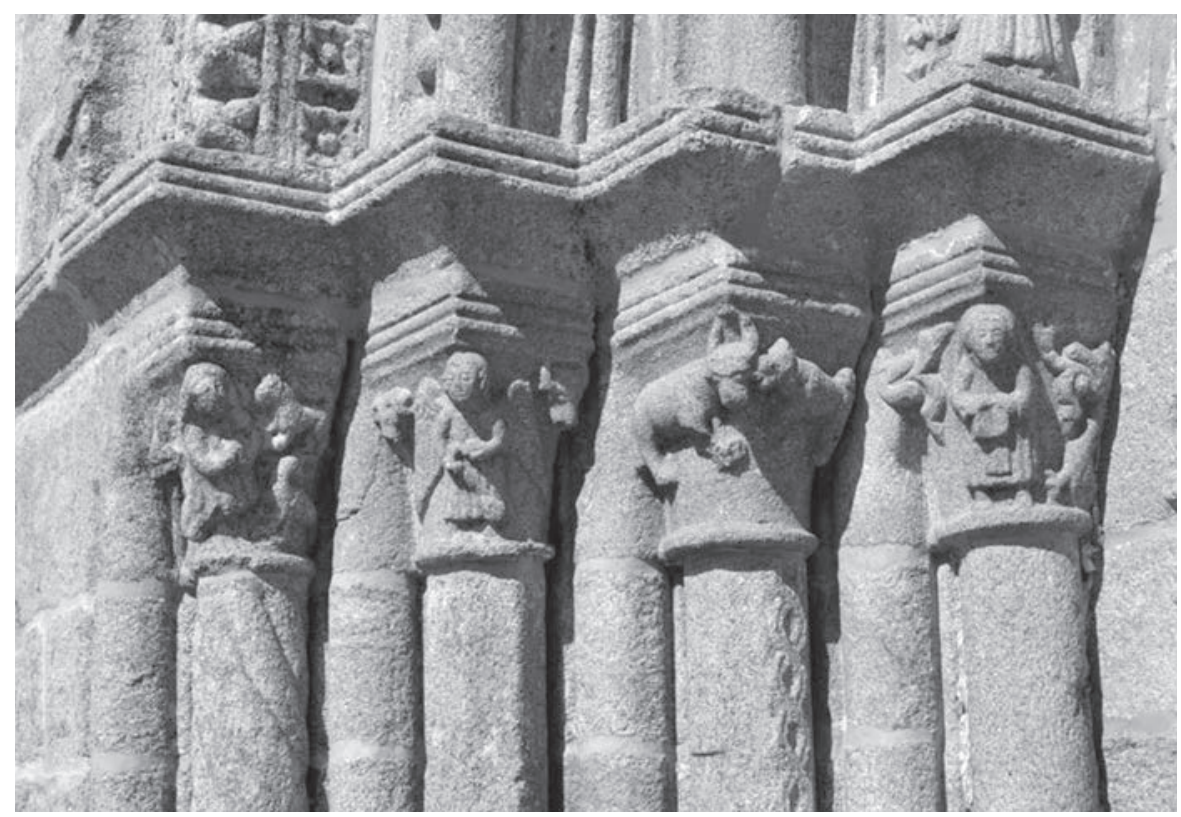

Lámina 5

dición mateana, en la que san José aparecía de pie y tras los magos los caballos ${ }^{82}$; no es este el caso. Tampoco presenta dudas la primera de las arquivoltas cuyas dovelas, en sentido longitudinal propio del gótico, están jalonadas por ángeles turiferarios — a la izquierda del espectador-, con sendos libros — la mayoría, en especial a ambos lados del dosel que se dispone sobre la Virgen-, con cartela - en el lado derecho-, o con sus manos juntas en gesto de oración - lado derecho- . Todos ellos evocan los que pueblan los arcosolios, con un cabello propio de las múltiples resurgencias mateanas.

Fiz de Solovio (1316), el de Doña Leonor (1323), el de Nuestra Señora de Belén en Santa Cristina de Fecha (1322-1323), Santa María a Nova de Noia (1327), San Benito del Campo (1330-1360), y, con posterioridad, los de Santa María a Nova de Santiago (1390), San Francisco de Betanzos (1397), Santo Domingo de A Coruña (fin.XIV-prin.XV), San Miguel de Figueroa en Abegondo (fin.XIV), San Nicolás de Cines (fines XIV), Santa María del Camino (Santiago, 1425), o Santa María do Azougue en Betanzos (1400-1430). Referencias a ellos en R. YzQuierdo Perrín, y C. Manso Porto, "Arte medieval (II)...", págs. 290 y 350. Sobre el de Nuestra Señora de Belén, véase Carmen Manso PoRto, "Un tímpano singular vinculado al arzobispo Fray Berenguel de Landoira (1317-1330) en Santa Cristina de Fecha (Santiago de Compostela)", Abrente 38/39 (2006/2007), págs. 75-116.

${ }^{82}$ Esta clasificación ha sido remarcada por Dolores Barral Rivadulla, "La epifanía: sus variantes iconográficas en la escultura bajomedieval gallega", en V Simposio Bíblico Español. La Biblia en el arte y en la literatura, Valencia-Pamplona, Universidad de Navarra, 1999, pág. 108. 
Lo que ofrece más dudas, y a su vez resulta más variado por cuanto recoge diversas influencias, es el conjunto de capiteles ${ }^{83}$. Si comenzamos por el flanco norte (lám. 5), apreciamos una figura femenina arrodillada con sus manos dispuestas en gesto de oración, rodeada por algunos animales ${ }^{84}$, entre los que se aprecian un águila y un león; se complementaría con el ángel turiferario del siguiente capitel, tras cuyas alas se observa un cáprido y un buey. Se trataría de una escena de la Anunciación, tema reiterado en numerosas portadas góticas, por cuanto supone la promesa de Redención gracias a la intervención mariana, en un santuario al que se peregrina para obtener o agradecer los favores de la Virgen. Los dos animales que acompañan a la Virgen se corresponderían con los símbolos de San Marcos y San Juan, mientras San Lucas se hallaría junto al ángel, símbolo, a su vez, de San Mateo. Por su parte, el carnero sería el animal para el sacrificio, futuro que aguarda a ese hijo que el arcángel Gabriel acaba de anunciar a María. A continuación se presenta un tema que copia uno de Santo Domingo de Ribadavia: una corrida de toros, identificada con la fiesta popular conocida como gallumbos, en la que había un toro enmaromado. El perro mordiendo la oreja del toro, era típico de la lidia ${ }^{85}$. Le sigue un monje que está sufriendo el ataque de dragones, mientras sostiene un libro en sus manos; se trata de figuras de afiladas dentaduras que evocan las de capiteles, frecuentes entre los mendicantes, como advertencias contra el pecado; el tema se hace más patente en el segundo capitel del lado opuesto (comenzando en este caso desde el tímpano). Aquí el personaje sería un laico, con indumentaria corta y cofia sobre sus cabellos, a quien los dragones, dos a cada lado entrelazados por sus colas, están mordiendo sus orejas. En ambos casos intentan distraer de la oración al monje, que porta el libro y al laico, cuyas manos expresan gesto orante. La presencia de dragones acechando y en especial dirigiéndose a las orejas ${ }^{86}$, según Fraga sería una imagen de tentación, que en algunos casos alude al pecado de la lengua o maledicencia en el que también incurren los que escuchan a los murmuradores ${ }^{87}$.

\footnotetext{
${ }^{83}$ Su iconografía está tratada en Marta Cendón Fernández, "Unha realidade histórica e a súa materialización artística: O mosteiro de Santa María da Franqueira / Una realidad histórica y su materialización artística: el monasterio de Santa María de A Franqueira", en F. Javier Alonso Docampo (dir.), Magnificat, Vigo, Santuario da Nosa Señora da Franqueira; Concello de Vigo; Diócesis TuiVigo, 2013, págs. 17-37.

${ }^{84}$ Rafael FonTOIRA SURís, Inventario de la riqueza monumental de la provincia de Pontevedra y el Camino de Santiago, Pontevedra, Diputación Provincial, 2001, pág. 527, indica que se trata de un león, un ave y un buey.

${ }^{85}$ R. Yzquierdo Perrín y C. Manso Porto, “Arte medieval (II)...”, pág. 292. C. Manso Porto, Arte gótico en Galicia..., tomo I, pág. 256.

${ }^{86}$ Marta Cendón Fernández, "El pecado en la capilla de San Andrés de la catedral de Tui", Quintana, 1 (2002), págs. 197-209.

${ }^{87}$ Dolores Fraga Sampedro, O templo de San Francisco de Ourense, Vigo, Fundación Caixa Galicia, 1999, pág. 40.
} 


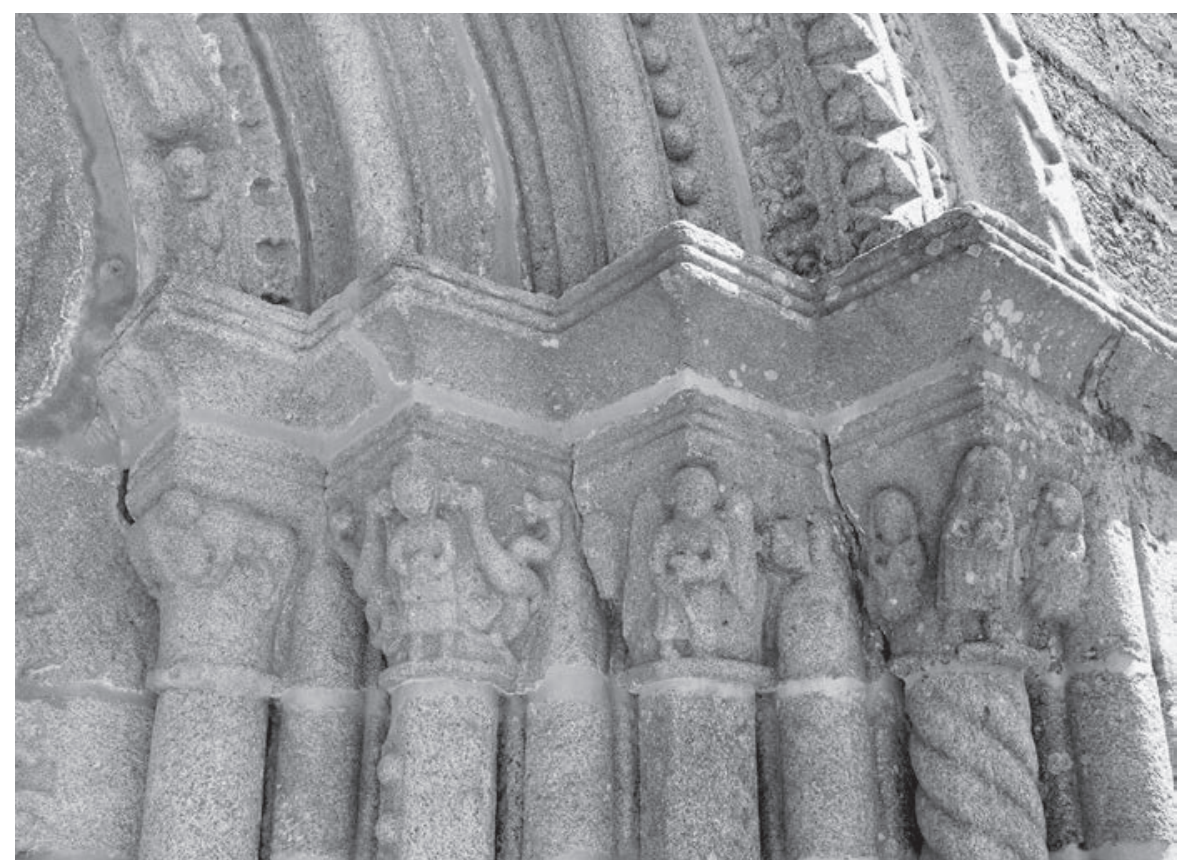

Lámina 6

No obstante cabe tener también en cuenta el papel del mal consejero, inductor al mal camino. En este sentido es preciso señalar lo que indicaba Sánchez Ameijeiras a propósito de las imprecaciones de los predicadores hacia los que se negaban a oir las enseñanzas del sermón, o que con sus burlas y charlas disturbaban la atención de los devotos ${ }^{88}$; a ello se suma lo que esta misma autora afirma sobre la particularidad de que los monstruos serpentiformes — dragones, áspides, serpientes-, híbridos de reptil, poseen una connotación referida a la sordera, según los Bestiarios medievales, donde se describe a los áspides como animales sordos, en relación con el salmo 57, 5, que compara a los calumniadores y a los jueces inicuos con áspides que se tapan $\operatorname{los} \operatorname{oidos}^{89}$.

Una nueva alusión a la lucha contra el mal se pone de manifiesto en el primer capitel del lado derecho (lám. 6), con dos cuadrúpedos afrontados, unidos por una sola cabeza, que, debido a su mutilación, impide saber si trata de híbridos o de lucha de animales.

\footnotetext{
${ }^{88}$ Rocío SÁnchez AmeiJeiras, "Espiritualidad mendicante y arte gótico", Semata, 7-8 (1996), vol. coord. por M. V. García Quintela Las religiones en la historia de Galicia, pág. 340.

${ }^{89}$ R. SÁnchez Ameiseiras, "Espiritualidad mendicante...", pág. 341. En realidad se trata de versículo 5 y no del 7 como indica esta autora.
} 
El colofón a todo el programa lo ofrecen los dos últimos capiteles. El tercero presenta a un nuevo ángel turiferario, rodeado por un animal y una cabeza humana, y el último donde se observan tres figuras femeninas, la primera de pie y las otras dos arrodilladas, las tres en gesto de oración. Podría tratarse de las tres Marías ante el sepulcro vacío ${ }^{90}$ a las que el ángel avisa de que Aquel a quien buscaban ya no está allí: ha resucitado (Lc 24, 4-6).

De ser así se completaría todo un ciclo de redención con María como protagonista: el arcángel Gabriel le anuncia que va a ser Madre de Dios, si bien en la escena la presencia del cáprido alude al animal del sacrificio, futuro que espera a ese Hijo. Ese anuncio se hace realidad en el tímpano: Cristo ha nacido y es adorado por los Magos, ellos mismos peregrinos — como

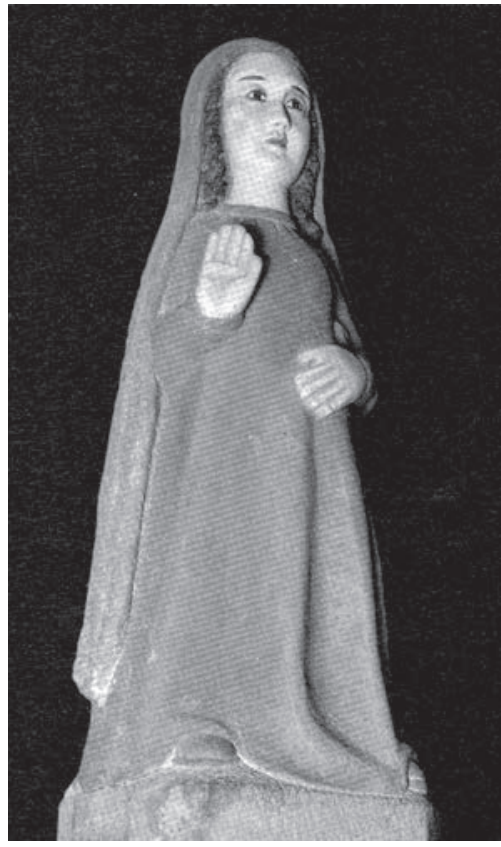

Lámina 7 todos aquellos que acudían a este santuario-, que lo reconocen como salvador de la humanidad, a la que ellos, hombres de "toda raza, lengua, pueblo y nación" (Ap. 5, 9) representan. Los evangelistas muestran el modo de vencer al mal, para lograr el fin prometido: morir al pecado y resucitar con Cristo (Rom. 6, 1-14). Eso es también lo que anhelan los peregrinos a A Franqueira: que la Virgen interceda para que sus pecados sean perdonados y puedan gozar de la vida eterna. Esa vida del cielo, que el propio dosel que se dispone sobre la cabeza de la Virgen — que evoca la Jerusalén Celeste- la resalta como Reina del Cielo.

La insistencia en la importancia de la Virgen en este monasterio, se pone de manifiesto en la existencia de una tercera imagen mariana medieval (lám.7), de nuevo exenta, que responde a un tipo iconográfico muy desarrollado en el gótico y que ofrece otra cara de María: se trata de una Virgen de la O, de la Esperanza o de la Expectación; también pétrea y datable en la segunda mitad del siglo XIV y como recoge Sánchez Ameijeiras ${ }^{91}$, responde a un tipo iconográfico y una advocación mariana introducida en Galicia en la primera mitad del siglo XIV por el taller de Pedro de Coimbra. No obstante esta imagen responde a talleres

\footnotetext{
90 Ya fue apuntado por R. FonTOIRA Surís, Inventario..., pág. 527.

91 R. SÁnchez Ameijeiras, "Las artes figurativas...”, pág. 117.
} 
locales con un plegado más rígido que otros ejemplos tudenses como el de San Esteban de Budiño, y se ha encontrado aislada y no formando un grupo de la Anunciación como suele ser frecuente ${ }^{92}$. No se puede olvidar, que la iglesia de San Esteban de Budiño debió de estar ligada al monasterio benedictino de San Salvador de Budiño, de nuevo un elemento que pone en relación con dicha orden y no el císter.

\section{CONCLUSIONES}

En definitiva, todo apunta a que un antiguo cenobio altomedieval recuperado como monasterio benedictino, se convierte en un importante santuario mariano, centro de peregrinación al que acuden atraídos por los milagros de la Virgen, gentes de diversos lugares de Galicia, según los documentos conservados. Dicho monasterio, quizá con el redescubrimiento de la imagen o potenciación de su culto, se reconstruye a finales del siglo XIII, bajo el episcopado de don Juan Fernández de Sotomayor I (1286-1323) y se afilia a la orden del císter siendo obispo don Juan Fernández de Sotomayor II (ca.1395-1423). Su reconstrucción se dataría concretamente entre 1293, fecha en la que tradicionalmente se consideraba su afiliación al císter y 1342, data que se recoge en un epígrafe bajo el tímpano con el nombre de Gonzalo I, abad que, como promotor, aparece inmerso en la escena de la epifanía, siguiendo modelos muy arraigados en el gótico gallego.

La insistencia en la iconografía mariana, bien como imagen de devoción, bien en escenas de la Anunciación y la Epifanía, revela que además de seguir modelos muy difundidos en el gótico, es un compendio de diversos aspectos que un santuario mariano debe promover: María como mujer de fe, que se fía del anuncio del ángel Gabriel y se ofrece para hacer su voluntad; como mujer de

\footnotetext{
92 Tipológicamente pertenecería a un grupo de piezas relacionables con el mundo portugués en el que también se incluiría, a juicio de Manso, la Virgen de la Colegiata iriense, el grupo del Museo de la catedral de Santiago, el de la iglesia de Salomé en Santiago, el grupo del pórtico tudense, la Virgen de Santa María de Budiño del Museo Diocesano de Tui, el grupo de la capilla funeraria de Santa María de Gracia de Monterrei, el de la Atalaya de Laxe, los relieves del arranque de la arquivolta externa de San Martín de Noia o los salmeres de un arcosolio de Santo Domingo de Ribadavia. En Carmen Manso Porto, "La escultura gótica y renacentista en Galicia", en La escultura gallega: el centenario de Francisco Asorey, Santiago de Compostela, Fundación A. Brañas, 1991, págs. 31-54, pág. 41 para la nota. A ellos añade en una publicación más reciente el de la portada occidental de Santa María do Azougue en Betanzos, y el de la portada sur de San Francisco de la misma localidad; véase R. Yzquierdo Perrín y C. Manso Porto, "Arte medieval (II)...", pág. 437. A ellos habría que añadir el grupo existente en el cementerio de Iria Flavia, al que aludimos en Marta Cendón Fernández, "Muerte y memoria en la Galicia medieval", en col. de Historia del Arte Gallego, Vigo, A Nosa Terra, [en prensa]. Todo ello recogido en Marta Cendón Fernández, La catedral de Tuy en época medieval, Pontevedra, Fundación Cultural Rutas del Románico-José Antonio Rodríguez Mouriño, 1995, pág. 61.
} 
esperanza, que sabe esperar y enseña a los fieles a tener confianza cuando acuden en su ayuda porque están desesperados por sus dolencias, tristezas, enfermedades...; como madre del salvador, que transmite la verdadera sabiduría, que predica la palabra que va a salvar al hombre del pecado; como madre del redentor quien se manifiesta a toda la humanidad, sin diferencias de razas o pueblos. Ella se convierte en la mejor intercesora entre todos los hombres y su propio hijo, por eso al santuario acudirán a lo largo de los siglos y hasta la actualidad numerosos peregrinos que seguirán diversos rituales comunes a los de otros santuarios marianos tanto gallegos como de otros lugares, con los que comparte similitudes en las leyendas de origen, en ritos y en las expresiones de devoción.

\section{BIBLIOGRAFÍA}

Andrade Cernadas, José Miguel, Monxes e mosteiros na Galicia medieval, Santiago de Compostela, Servicio Publicaciones USC, 1995.

Andrade Cernadas, José Miguel, El monacato benedictino y la sociedad de la Galicia medieval (siglos X al XIII), Sada, Edicións do Castro, 1997.

Andrade Cernadas, José Miguel, "O monacato medieval en Galicia”, en Galicia Terra Unica. Galicia románica e gótica, Ourense, Xunta de Galicia, 1997, págs. 62-69.

Andrade Cernadas, José Miguel, "Los modelos monásticos en Galicia hasta el siglo XI", Archivo Ibero-Americano, LXV/252 (2005), págs. 587-609.

Andrade Cernadas, José Miguel, "San Rosendo y Celanova", en Rudesindus. "San Rosendo. Su tiempo y su legado", Congreso celebrado en Mondoñedo, Santo Tirso (Portugal) y Celanova los días 27, 28, 29 y 30 de junio de 2007, Santiago de Compostela, Xunta de Galicia, 2009, págs. 239-250.

Álvarez, Arturo, Guadalupe: arte, historia y devoción mariana, Madrid, Stvdivm, 1964.

Aponte, Vasco de: Recuento de las casa antiguas del reino de Galicia, Santiago de Compostela, Xunta de Galicia, 1986.

Ávila y La Cueva, Francisco, Historia civil y eclesiástica de la ciudad de Tuy y su obispado, 4 tomos, Archivo de la Catedral de Tui, 1852. Ed. facs., Santiago de Compostela, Consello da Cultura Galega, 1995.

Barral Rivadulla, Dolores, "La epifanía: sus variantes iconográficas en la escultura bajomedieval gallega", en $V$ Simposio Bíblico Español. La Biblia en el arte y en la literatura, Valencia-Pamplona, Universidad de Navarra, 1999, págs. 105-116.

Barral Rivadulla, Dolores, Arte y arquitectura en el Convento de San Francisco de A Coruña, Ferrol, Edicións Embora, 2007.

Caamaño Martinez, Jesús M. a "Seis tímpanos compostelanos de la adoración de los Reyes", Archivo Español de Arte, 31 (1958), págs. 330-338.

Caamaño Martinez, Jesús M. ${ }^{\text {, }}$ Contribución al estudio del gótico en Galicia, Valladolid, Universidad, 1962.

Cardeso Liñares, José, Santuarios marianos de Galicia: historia, arte y tradiciones, A Coruña, Fundación Caixagalicia, 1995. 
Castro Fernández, Xosé Xntón, El santuario de la Virgen de la Barca: tradición, arte y leyenda, Santiago de Compostela, tesis de Licenciatura dir. Ramón Otero Túñez, Universidad de Santiago de Compostela, 1980, 2 vols.

Cendón Fernández, Marta, Los Sotomayor ante la muerte y su reflejo en el Arte (ss.XIV$X V$ ), Santiago de Compostela, tesis de licenciatura inédita, dir. Manuel Núñez Rodríguez, USC, 1991.

Cendón Fernández, Marta, La catedral de Tuy en época medieval, Pontevedra, Fundación Cultural Rutas del Románico-José Antonio Rodríguez Mouriño, 1995.

Cendón Fernández, Marta y Barral Rivadulla, Dolores, "Donantes y promotores: su imagen en la plástica gótica gallega”, Semata, 10 (1999), monográfico dedicado a Cultura, poder y mecenazgo, págs. 389-418.

Cendón Fernández, Marta, "El pecado en la capilla de San Andrés de la catedral de Tui", Quintana, 1 (2002), págs. 197-209.

Cendón Fernández, Marta, "Muerte y memoria en la Galicia medieval", en col. de Historia del Arte Gallego, Vigo, A Nosa Terra, [en prensa].

Cendón Fernández, Marta y Chao Castro, David, "El Císter en Galicia”, en Los cistercienses en el reino de León hasta 1250, León, Instituto Leonés de Cultura, 2011.

Enríquez Paradela, M. ${ }^{a}$ Carmen, Colección Diplomática del monasterio y convento de Santo Domingo de Ribadavia, Ourense, Museo Arqueolóxico Provincial, 1987 (Boletín Avriense, Anexo 8).

Fernández Pérez, Clodio, "La romería de Nosa Señora de Franqueira", Narria: revista de artes y costumbres populares, 77-78 (1997), págs.41-46.

Fernández Suárez, Gonzalo Francisco, La nobleza gallega entre los siglos XIV-XV. Los Sarmiento Condes de Ribadavia, Santiago de Compostela, El Eco Franciscano, 2002.

Filgueira Valverde, José, "Miscelánea. Sobre Pay Sorred de Sotomayor", Museo de Pontevedra, III (1945), págs. 232-233.

Fontoira Surís, Rafael, Inventario de la riqueza monumental de la provincia de Pontevedra y el Camino de Santiago, Pontevedra, Diputación Provincial de Pontevedra, 2001.

Fraga Sampedro, Dolores, O templo de San Francisco de Ourense, Vigo, Fundación Caixa Galicia, 1999.

Fraga Sampedro, Dolores, "El poder de la palabra: imágenes de predicación en la Edad Media Hispana”, e-Spania [En línea], 3 juin 2007, Puesto en línea el 21 juin 2007 [Consultado: 5 de mayo de 2014].

Galindo Romeo, Pascual, Tuy en la Baja Edad Media s.XII-XV, Madrid, El Noticiero, 1923.

García Oro, José, La nobleza gallega en la Baja Edad Media, Santiago de Compostela, Liceo Franciscano, 1980-81.

García Oro, José y Portela Silva, M. ' José, A monarquía e os mosteiros gelegos no século XVI. A hora da recuperación, Noia, Grupo Filatélico e Numismático de Noia, 2009.

Gómez Rascón, Máximo, Theotókos. Vírgenes medievales de la diócesis de León, León, Edilesa, 1996.

Iglesias Almeida, Ernesto, "El monasterio de Santa María de Tomiño", Tui. Museo y archivo histórico diocesano, VI (1992), págs. 75-102. 
Limia Jardón, Francisco Xavier, "Santa María de A Franqueira", en Monasticon cisterciense gallego, coordinado por Fray Damián Yáñez Neira, León, Edilesa, 2000, vol I, págs. 270289.

Llinares García, Mar, Os mouros no imaxinario popular galego, Santiago de Compostela, Servicio de Publicacións USC, 1990.

López Ferreiro, Antonio, Historia de la S.A.M.I. de Santiago de Compostela, tomo VI, Santiago de Compostela, Imp. y enc. del Seminario Conciliar Central, 1901.

López López, Roberto Javier, "Ermitas y santuarios marianos en Galicia en la Edad Moderna”, en M.G. Meloni, O. Schena (coord.): Culti, santuari, pellegrinaggi in Sardegna e nella Penisola Iberica tra medioevo ed età contemporánea, Genova, Brigati, 2006, págs. 231-273.

Alonso Docampo, F. Javier (dir.), Magnificat, Vigo, Santuario da Nosa Señora da Franqueira; Concello de Vigo; Diócesis Tui-Vigo, 2013.

Manso Porto, Carmen, "La escultura gótica y renacentista en Galicia", en La escultura gallega: el centenario de Francisco Asorey, Santiago de Compostela, Fundación A. Brañas, 1991, págs. 31-54

Manso Porto, Carmen, Arte gótico en Galicia: los dominicos, La Coruña, Fundación Pedro Barrié de la Maza, 1993, 2 tomos.

Manso Porto, Carmen, "Un tímpano singular vinculado al arzobispo Fray Berenguel de Landoira (1317-1330) en Santa Cristina de Fecha (Santiago de Compostela)", Abrente 38/39 (2006/2007), págs. 75-116.

Martínez Ruiz, Enrique (coord.), El peso de la iglesia. Cuatro siglos de Órdenes Religiosas en España, Madrid, Actas, 2004.

Moralejo Álvarez, Serafín, Escultura gótica en Galicia (1200-1350), resumen de la tesis doctoral, Santiago de Compostela, 1975.

Pereira Salgado, Ana, El santuario de Nuestra Señora de las Ermitas, Ourense, Deputación Provincial, 2008.

Pérez Rodríguez, Francisco Javier, Mosteiros de Galicia na Idade Media, Ourense, Deputación provincial de Ourense-Fundación Caixa Galicia, 2008.

Portela Silva, Ermelindo, La región del obispado de Tuy en los siglos XII a XV. Una sociedad en la expansión y en la crisis, Santiago de Compostela, El Eco Franciscano, 1976.

Portela Silva, M. ${ }^{a}$ José (ed.), Documentos da catedral de Lugo. Século XV, León, Consello da Cultura Galega, 2005.

Rey Caíña, José Ángel, “La Abadía de Ferreira Pallares desde 898 hasta 1300”, Cuadernos de Estudios Gallegos, 34, fasc. 99 (1983), págs. 89-115.

Rivadulla Porta, Xosé E., Santuario de Ntra. Sra. de la Barca-Muxía: leyenda, historia, arte, folklore, La Coruña, Imprenta Comercial, 1980.

Risco, Vicente, "Etnografia, cultura espiritual”, en Otero Pedrayo, Ramón (dir.): Historia de Galiza, Madrid, Akal, págs. 255-777.

Rodríguez Fraiz, Antonio, "Costumbres populares de las iglesias y santuarios marianos de Galicia”, Museo de Pontevedra, 14 (1960), págs. 89-141. 
Romaní Martínez, Miguel, Portela Silva, M. ${ }^{a}$ José, Rodríguez Suárez, M. ${ }^{a}$ Pilar, Vázquez Bertomeu, Mercedes, Colección Diplomática de Santa María de Oseira (Ourense) 13101399, vol.III, Santiago de Compostela, Tórculo, 1993.

Sánchez Ameijeiras, Rocío, "Las artes figurativas en los monasterios cistercienses medievales gallegos", en Rodrigues, Jose, Valle Pérez, José Carlos (coords.). Arte del Císter en Galicia y Portugal, Fundación Calouste Gulbenkian-Fundación Pedro Barrié de la Maza, 1998.

Sánchez Ameijeiras, Rocío, "Espiritualidad mendicante y arte gótico", Semata, 7-8 (1996), ejemplar dedicado a Las religiones en la historia de Galicia, coord. por M. V. García Quintela, págs. 333-353.

Simón Pardo, Jesús, La devoción a la Virgen en España. Historias y leyendas, Madrid, Palabra, 2003.

Sá Bravo, Hipólito de, El monacato en Galicia, La Coruña, Libregal, vol.II, 1972.

Seijas Montero, María, "Aproximación a la actividad económica del monasterio cisterciense de Santa María de A Franqueira", en Galicia monástica. Homenaxe a María José Portela Silva, Santiago de Compostela, Universidade de Santiago de Compostela, 2009, págs. 245-265.

Solla García, Andrés María, Resumen histórico del santuario de Santa María de Aguassantas en Cotovad y novena a la Santísima, Pontevedra, Tipografía de Julio Antúnez, 1930.

Río Ramos, Laura, "Santa María da Franqueira", en Mosteiros e conventos da Península Ibérica. Galicia, A Coruña, Hércules, 2008, tomo I, págs. 16-42.

Valle Pérez, José Carlos, Santa María de A Franqueira. Monasterio Cisterciense, León, Edilesa, 2003.

Vázquez Rouco, Sergio, San Xoán de Poio: monasterio, coto, parroquia, Pontevedra, Deputación Provincial de Pontevedra, 1998.

Vila Botanes, Suso, A casa de Soutomaior (1147-1532), Noia, Toxosoutos, 2010.

Yzquierdo Perrín, Ramón y Manso Porto, Carmen, “Arte medieval (II)”, en Galicia. Arte, tomo XI, La Coruña, Hércules, 1996. 